\title{
A Formula for Disobedience: Jansenism, Gender, and the Feminist Paradox*
}

\author{
Daniella Kostroun \\ Stonehill College
}

On the morning of June 10, 1664, the archbishop of Paris, Hardouin de Péréfixe, met with Marguerite de Sainte-Gertrude Dupré, a nun at the convent of Port Royal de Paris, for a one-on-one conversation. His purpose for this meeting was to change Dupré's mind about her refusal to sign a formula condemning the Augustinus (1640), a theological study by Cornelius Jansen, the late bishop of Ypres. According to Dupré's own account, the archbishop began the interview by offering her a chair and expressing his confidence that he could ease her doubts. He asked her, "Why, my sister, can you not sign? One must not say that one will not do something out of stubbornness, one must have one's reasons; ah, tell them to me."' When Dupré responded, "It would not be right, Monsignor, to fail in what you wish from us without reason, and if my conscience would allow me ...,"2 he interrupted her abruptly: "My conscience ... my conscience! Does your conscience permit you to disobey

* Research for this article was supported by the Erasmus Institute of the University of Notre Dame and the Center for Seventeenth- and Eighteenth-Century Studies at the University of California, Los Angeles. Various sections were presented at the Western Society for French History conference in 2000, the American Catholic Historical Association meeting in 2001, the Culture and Authority in the Baroque conference at the William Andrews Clark Memorial Library in Los Angeles in February 2001, and the North American Society for Seventeenth-Century French Literature conference in 2001. A full version was presented to the Triangle French Studies Group in February 2002. I have benefited from many questions and comments raised on those occasions. I want to thank Johnny Goldfinger, Sarah Maza, Michèle Longino, John Lyons, William Reddy, Susan Rosa, Malina Stefanovska, Philip Stewart, and Dale Van Kley for their insights on earlier drafts.

${ }^{1}$ Marguerite de Sainte-Gertrude Dupré, "Relation de ma Soeur Marguerite Gertrude," in Relation de ce que s'est passé à Port Royal depuis le commencement de l'année 1664 jusqu'au l'enlèvement des Religieuses, qui fut le 26 Août de la même année, in Divers actes, lettres et relations des religieuses de Port-Royal du Saint Sacrement, touchant la persécution et les violences qui leur ont été faites au sujet de la signature du Formulaire (Utrecht, 1724), p. 14: "Pourquoi ma soeur ne le pouvez-vous pas signer, quelle raison en avez vous? Il ne faut pas dire par entêtement, je ne puis faire une chose, si on n'en a des raisons, ah: dites les moi."

${ }^{2}$ Ibid.: "Cela ne seroit pas juste, M[onseigneur] de ne pas faire ce que vous souhaitez de nous sans aucunes raisons, et si ma conscience me le pouvoit permettre."

[The Journal of Modern History 75 (September 2003): 483-522]

(C) 2003 by The University of Chicago. 0022-2801/2003/7503-0001 $\$ 10.00$

All rights reserved. 


\section{Kostroun}

your archbishop?"3 Dupré managed only to say "Monsignor ..." before he interrupted her again: "Keep quiet, listen to me: do you not know well that I have the right to command you and that you are obligated to obey me?"4 According to Dupré's testimony, the archbishop interrupted her in this manner more than six times before he ended the interview by yelling, "Get out of here, there is not a drop of reason in you." ${ }^{5}$ Dupré wrote that he appeared to be so angry with her that she left without asking him for the customary benediction.

The account of Péréfixe's interrogation of Dupré brings out the clash between her conscience and his demand for unquestioning obedience, a central issue of the Jansenist conflict of the seventeenth century. ${ }^{6}$ Dupré was one of the eighty-seven Port Royal nuns who believed that Jansen's technical threevolume study of original sin and the grace necessary to overcome it contained the true doctrine of Augustine. These women, along with a handful of male supporters, refused to denounce the work in spite of its condemnation by two papal bulls, in 1653 and 1656, respectively. ${ }^{7}$ The political implications of their refusal were underscored by Louis XIV's command in 1661 that all members of the church sign a formula witnessing their adherence to the bulls. ${ }^{8}$ While most members of the church signed-Louis XIV threatened to block the temporal income from church benefices for those who did not comply - the Port

${ }^{3}$ Ibid.: "Ma conscience ... ma conscience! Est-ce que votre conscience vous permet de ne pas obéir a votre Archevêque?"

${ }^{4}$ Ibid.: "Taisez-vous, écoutez-moi: Ne sçavez-vous pas bien que j'ai droit de vous commander, et que vous êtes obligée de m'obéir?"

${ }^{5}$ Ibid., p. 16: "Allez sortez d'ici, il n'y a point de raison à vous."

${ }^{6}$ The literature on Jansenism is vast. For an introduction in English to this literature, see Alexander Sedgwick, Jansenism in Seventeenth-Century France: Voices from the Wilderness (Charlottesville, Va., 1977), and, more recently, William Doyle, Jansenism: Catholic Resistance to Authority from the Reformation to the French Revolution (New York, 2000).

${ }^{7}$ The two bulls were Cum Occasione (1653), published by Pope Innocent X, and Ad Sacram (1656), published by Pope Alexander VII. Cum Occasione condemned five propositions that had come under dispute upon the publication of Jansen's Augustinus. Ad Sacram affirmed that these five propositions (four of which were declared heretical and the fifth one false) derived from Jansen's book. For a list of the five propositions in English, see Sedgwick, Jansenism, p. 68.

${ }^{8}$ The text of the formula reads: "I submit sincerely to the constitution of Innocent $\mathrm{X}$ of May 31,1653, according to its proper meaning as set forth in the constitution of our Holy Father Alexander VII of October 16, 1656. I recognize that I am obliged to obey these constitutions, and I condemn with heart and mouth the doctrine contained in the five propositions of Jansenius in his book entitled Augustinus that two popes and the bishops have condemned, the doctrine that is not at all that of Saint Augustine, entirely misinterpreted by Jansenius": Sedgwick, Jansenism, p. 108. The formula was the most blatant expression of Louis XIV's political involvement in religious affairs. But the political implications of the quarrel were felt as far back as 1653, when Louis XIV issued the patent letters to receive the bull Cum Occasione in France. 
Royal nuns remained the king's most stubborn opponents. When Louis XIV appointed Archbishop Péréfixe to his post in the spring of 1664, Péréfixe made it his priority to subjugate the Port Royal women. ${ }^{9}$ He punished the nuns for their resistance by refusing them the sacraments, exiling them to other convents, and finally isolating them together under house arrest reinforced by armed guards and unsympathetic confessors. Nevertheless, even under these conditions all but eleven of the nuns remained steadfast. This punishment continued until the Peace of Clement IX in 1669-a shaky truce forged by Louis XIV, a group of French bishops, and Pope Clement IX that defused the Jansenist debates in France for about thirty years. ${ }^{10}$

The Port Royal nuns, long recognized for their heroic commitment to their beliefs, are also remarkable for the way in which they engaged fundamental assumptions about gender, order, and authority to oppose Louis XIV's efforts to control individual conscience..$^{11}$ As women, the nuns did not enjoy the same authority as male clerics to oppose the formula by questioning the procedural and hermeneutic methods used by Rome to condemn Jansen's text. Instead, the Port Royal nuns resisted the formula by claiming that their subordinate position in the church rendered them incapable of passing judgment on Jansen's text in the first place. In other words, the nuns used gender-that is, assumptions about the "natural" quality of female inferiority_-paradoxically, to uphold their right of conscience and, by extension, their right to oppose what

${ }^{9}$ The Port Royal nuns fell under the authority and jurisdiction of the archbishop of Paris in 1664 because the convent's reforming abbess, Angélique Arnauld, had moved the convent from the jurisdiction of the Cistercian order to that of the Parisian diocese in 1626. For an account of this move and the reasons behind it, see Louis Cognet, Mère Angélique et St. François de Sales (Paris, 1951), pp. 176-221.

${ }^{10}$ Sedgwick, Jansenism, pp. 137-38.

${ }^{11}$ According to Dale Van Kley, one of the most significant developments of Bourbon absolutism was the monarchy's attempt to exert greater control over individual conscience as a way to "place itself securely above the confessional fray" in the wake of the Wars of Religion: Dale Van Kley, The Religious Origins of the French Revolution (New Haven, Conn., 1996), p. 35. Van Kley's study of the Jansenist challenge to this "Bourbon solution" and its contribution to the development of revolutionary language and ideology has opened a new field in the study of Jansenism in terms of eighteenthcentury political culture and the origins of the French Revolution. Previously, Jansenist scholarship focused primarily on questions of Jansenist theological orthodoxy, on the contribution of Jansenist authors to baroque and classical literature, and on the origins of Enlightenment rationalism in Jansenist philosophy and religious polemic; see the bibliographic essay in Catherine Maire, "Port Royal: La Fracture Janséniste," in Les lieux de mémoire, ed. Pierre Nora, 3 vols. (Paris, 1992), 3:471-529. While all Jansenist scholars have acknowledged the importance of the nuns to Jansenist history, they have relegated them to their own history in the form of monastic history, the history of spirituality, and spiritual biography; see F. Ellen Weaver, "Port Royal," in Dictionnaire de spiritualité, 17 vols. (Paris, 1932-95), 13:1932-52. 


\section{Kostroun}

the Jansenists considered to be an illegitimate use of authority on Louis XIV's part. Such use of a gender-based paradox to assert these rights in a patriarchal system that denied women all political authority accords with Joan Scott's definition of feminism as the history of women with "only paradoxes to offer." ${ }^{2}$ For Scott, feminists are those who raise and confront the paradoxes of an ideological system that espouses universal equality (in this case, the spiritual equality of all Christians before God) at the same time that it upholds sexual difference as a natural fact and basis for social (and spiritual) differentiation. She writes, "The paradoxes I refer to are not the strategies of opposition, but the constitutive elements of feminism itself."13 By defining feminism as "paradoxical in expression," Scott creates the possibility for a comparative approach to feminism that subordinates ideological differences among women to a structure of agency. ${ }^{14}$ Scott's definition has not gone without challenge, but the Port Royal nuns illustrate how well "reading for paradoxes" can reveal female struggles for political authority long before the development of modern feminism..$^{15}$

The key to the feminist paradox at Port Royal lies in recognizing the nuns' self-identification as Catholic reformers and as defenders of Jansen's Augustinus under Louis XIV's divine right monarchy. ${ }^{16}$ When Archbishop Péréfixe demanded that the nuns sign the formula, they could not oppose the formula outright because this would imply an act of judgment of theological texts on a par with men. Such a judgment would have been seen as a violation of the church command for female silence and obedience and would have ruined their credibility as Catholic reformers. ${ }^{17}$ Rather than risk alienating themselves

${ }^{12}$ Joan Wallach Scott, Only Paradoxes to Offer: French Feminists and the Rights of Man (Cambridge, Mass., 1996), p. 4. Scott's phrase "only paradoxes to offer" comes from Olympe de Gouges's Le bonheur primitif de l'homme (Paris, 1788).

${ }^{13}$ Scott, Only Paradoxes, p. 5.

${ }^{14}$ Ibid., p. 16.

${ }^{15}$ I stress the word "authority" here because contention, whether involving gender or other issues, was not based on rights in early modern France. It was based on questions of authority and subordination, jurisdiction and obedience; see Constance Jordan, Renaissance Feminism (Ithaca, N.Y., 1990), pp. 12-19. For a critique of Scott's theory of feminism as paradox, see Karen Offen, European Feminisms, 1700-1950 (Stanford, Calif., 2000), pp. 13-15.

${ }^{16}$ As Catholic reformers, the Port Royal nuns were examples of a much broader trend among French women religious to revitalize the Catholic Church in the seventeenth century. For a discussion of this movement and an analysis of how women's quest for a more active role in spiritual matters often resulted in challenges to institutionalized misogyny, see Elizabeth Rapley, The Dévotes: Women and Church in Seventeenth-Century France (Montreal, 1990).

${ }^{17}$ The epistles of Paul provide the scriptural basis for the church's command for female silence and obedience. The relevant passages include: "Let your women keep silence in the churches: for it is not permitted unto them to speak; but they are commanded to be under obedience, as also saith the law. And if they will learn any thing, 
from the church in this way, the nuns sought to undermine the formula by signing with a restrictive clause stating that such matters were "above their profession and their sex." By defining themselves in terms of their group identity, or order, and by invoking the laws restricting women's ability to teach and speak within the church, the nuns opposed Louis XIV's religious policies while remaining within the legitimate confines of political absolutism and the Catholic Church. Their tactic drew upon an old paradox within Christianity that the dictates for Christian obedience actually provided autonomy for resistance. In the previous century, Erasmus (1469-1536) had used this paradox to argue that women had the right to resist their husbands' authority if their husbands led them to disobey God. ${ }^{18}$ At about the same time, Luther (14831564) had used this paradox to justify civil disobedience against secular leaders in the name of Christian liberty. ${ }^{19}$ In the case of the Port Royal nuns, we see a practical combination of both arguments in their insistence on sexual difference as justification for their disobedience to the king.

At the same time that the nuns drew upon this old paradox to resist the formula, their position posed a new paradox, one that arose out of a transformation in religion in the sixteenth and seventeenth centuries. This transformation, according to Wilfred Cantwell Smith, involved a change in the definition of "religion" from "faith" or "a dynamic of the heart" to the systems of ideas and practices that people developed in the hope of instituting or evoking a genuine recognition of God. ${ }^{20}$ This new objectification of religion, which developed in the wake of the Reformation, prompted reformers in both Protestant and Catholic circles increasingly to define their religion as a set of systematic propositions and practices. ${ }^{21}$ Louis XIV's anti-Jansenist formula was an example of this development, since the purpose of the formula was to eradicate heresy by commanding all signers to condemn "with heart and mouth" five propositions allegedly drawn from Jansen's Augustinus. When Louis XIV ordered the nuns to sign the formula, he created a new problem for them because to condemn the propositions demanded a certain degree of theological knowledge on the part of the faithful for willful, orthodox belief. This need for knowledge posed a paradox for the Port Royal nuns, since the church

let them ask their husbands at home: for it is a shame for women to speak in the church" (1 Cor. 14:34-37) and "I suffer not a woman to teach, nor to usurp authority over a man, but to be in silence. For Adam was first formed, then Eve. And Adam was not deceived but the woman being deceived was in the transgression" (1 I Tim. 2:12-14). See also 1 Cor. 2:3, 8; Eph. 5:22; Col. 3:18; 1 Tim. 2:11; 1 Pet. 3:1.

${ }^{18}$ Jordan, p. 58.

${ }^{19}$ Quentin Skinner, The Foundations of Modern Political Thought, 2 vols. (Cambridge, 1978), 2:16-17.

${ }^{20}$ Wilfred Cantwell Smith, The Meaning and End of Religion (New York, 1978), p. 38 .

${ }^{21}$ Ibid., pp. $39-42$. 
customs barring women from reading and teaching theology were based on the belief that women were incapable of these skills. How could the nuns sign a document repudiating a set of theological propositions if the church ruled that women were "naturally" ignorant of theology? The question became an urgent one for Port Royal during the formula crisis, because if women were incapable of theological learning, as church custom maintained, then the nuns were incapable of taking sides in a theological dispute-incapable of either orthodoxy or heresy. By insisting on their theological ignorance, the Port Royal nuns verged on this unexplored terrain of argument, which, as we shall see, became a concern for them once Archbishop Péréfixe introduced his doctrine of "human faith" as the rationale for why they should sign. This doctrine alarmed the nuns because, although Péréfixe claimed that it rendered their signatures into nothing more than an external sign of female submission to his authority, the nuns interpreted it as a denial of women's spiritual equality in its demand that they submit to human authorities before submitting to God. In their interrogations the nuns countered Péréfixe's doctrine by distinguishing between theological knowledge and knowledge that can be gained, even by women, through the natural senses and reason. In the end, the nuns' defense of their capacity for reason, an argument that lay close to the heart of all seventeenth-century feminists, formed the basis of their resistance..$^{22}$ Through reason, they ultimately defended their spiritual equality and justified their opposition to Louis XIV.

This essay examines the feminist paradox at Port Royal in two stages. First, by following the events leading up to Péréfixe's interrogation of the nuns in 1664, we will see how the nuns developed a strategy of resistance to Louis XIV's formula that was, paradoxically, only a higher form of obedience. Next, we will see how the nuns confronted male authorities with this paradox as we examine the interrogation reports provided by Gertrude Dupré and two other nuns, Angélique de Saint-Jean Arnauld d'Andilly and Marguerite de SainteChristine Briquet. These reports highlight the three discourses at the core of Port Royal's resistance: (1) the "natural" quality of female submission, (2) the authority of reason to determine religious orthodoxy, and (3) the rule of law in matters of jurisdiction and order. These discourses all figured into larger debates at the time about the roots of legitimate authority in gender, religion, and law that were of great interest to the political and social elite of seventeenth-century France..$^{23}$ The nuns' mastery of these discourses attests to the

${ }^{22}$ Siep Stuurman, “'L'égalité des sexes qui ne se conteste plus en France': Feminism in the Seventeenth Century," in Perspectives on Feminist Political Thought in European History from the Middle Ages to the Present, ed. Tjitske Akkerman and Siep Stuurman (London, 1998), pp. 67-84; Erica Harth, Cartesian Women: Versions and Subversions of Rational Discourse in the Old Regime (Ithaca, N.Y., 1992), p. 8.

${ }^{23}$ Siep Stuurman, "Literary Feminism in Seventeenth-Century Southern France," 
presence within the convent of highly educated women from families in the legal and administrative professions. ${ }^{24}$ In addition to examining the intellectual content of these interrogations, we will also consider them in terms of their literary qualities. Although the nuns presented these texts as mere transcripts of their interrogations, their accounts follow many of the literary conventions used by women writers in the sixteenth and seventeenth centuries ranging from Saint Teresa of Avila to the précieuses of the Parisian salons. In addition, these reports bear a close resemblance to the first ten letters of Pascal's Provincial Letters in the way they use dialogue, humor, and a naive posturing to undermine Péréfixe's doctrine of human faith. Their resemblance to these famous polemical letters, which mark the first public campaign to champion the power of common sense to confound theological error, suggests that the nuns composed the interrogations to persuade a reading public of the justice of their cause. ${ }^{25}$ It is possible, therefore, that the nuns' reports represent a premeditated publishing strategy rather than simple, faithful transcripts of their interrogations as claimed. ${ }^{26}$ By way of conclusion, this essay will examine the conse-

Journal of Modern History 71 (1999): 1-27; James Farr, Authority and Sexuality in Early Modern Burgundy (Oxford, 1995), pp. 13-24. For the intellectual roots of discourses on the qualities of dominance and subordination as "natural" to men and women, respectively, see Ian Maclean, Woman Triumphant: Feminism in French Literature, 1610-1652 (Oxford, 1977), pp. 1-24.

${ }^{24}$ I am interpreting these discourses as the nuns' "cultural resources," following the methodology of Natalie Zemon Davis in Women on the Margins: Three SeventeenthCentury Lives (Cambridge, Mass., 1995), pp. 7-8. On the social background of the nuns, see William Ritchey Newton, "Port Royal and Jansenism: Social Experience, Group Formation and Religious Attitudes in Seventeenth-Century France" (Ph.D. diss., University of Michigan, 1974). Newton finds 22 out of the 111 nuns in 1661 (19.8 percent) to be from families in the legal and administrative professions. These women held most of the positions of power within the convent. Newton's definition of "legal" families includes lawyers at all levels of the financial spectrum. He associates administrative families, most of whom worked as maîtres de requêtes, with parlementaire families because most of them were former parlementaires and continued to have strong ties to the palais through family and finance: Newton, pp. 269, 250-58, 306-7.

${ }^{25}$ Van Kley (n. 11 above), p. 94.

${ }^{26}$ Unfortunately, I have not been able to locate the original manuscript copies of these interviews. Nor can I prove that they circulated in public in 1664. All I know is that they were published along with other reports of Péréfixe's visits to Port Royal in Divers actes, lettres et relations des religieuses de Port-Royal du Saint Sacrement, touchant la persécution et les violences qui leur ont été faites au sujet de la signature du Formulaire (n. 1 above). I also know from Angélique de Saint-Jean Arnauld d'Andilly's "captivity journal" that at least some of the reports published in 1724 had circulated in 1664. In this journal, Angélique de Saint-Jean recounts how Péréfixe complained to her in the winter of 1664 about these reports, especially one in which the nuns quoted him as calling the abbess pimbêche (battle-ax) to her face. He denied this claim and accused Angélique de Saint-Jean and her fellow nuns of inventing false 
quences of the feminist paradox at Port Royal for the study of early modern feminism.

\section{The Formula Crisis at Port Royal}

The politico-religious struggle over the formula began in 1661, when Louis XIV commanded all members of the French clergy formally to condemn five propositions allegedly drawn from Jansen's Augustinus; members of the clergy were called upon to affix their signatures to an official document listing and renouncing these propositions. Although Louis XIV's demand for signatures triggered the crisis, the problem that the formula tried to address had already been around for almost twenty years. It began with the publication in 1640 of Jansen's Augustinus, a posthumously published study of Augustinian theories of grace and predestination. ${ }^{27}$ Although it purported to be an objective examination of patristic doctrine, Jansen's text launched a vicarious attack against contemporary Molinist theology and the Jesuit order in its sharp critique of the Pelagian heresy. ${ }^{28}$ A group of theologians at the Sorbonne, backed by Cardinal Richelieu, responded to Jansen's attack by charging that certain passages from the Augustinus were heretical and sending the book to Rome for papal condemnation. ${ }^{29}$ In 1653, Pope Innocent X condemned five propositions from Jansen's text in the papal bull Cum Occasione. ${ }^{30}$ Antoine Arnauld, the younger brother of Port Royal's reforming abbess Angélique Arnauld and a theologian at the Sorbonne, protested the bull at this time by arguing that the doctrine condemned by the pope was indeed heretical but that it did not appear

rumors about his treatment of them; see Angélique de Saint-Jean Arnauld d'Andilly, Relation de la captivité d'Angélique de Saint-Jean Arnauld d'Andilly, ed. Louis Cognet (Paris, 1954). As for my suggestion that the nuns compiled these interrogations with future publication in mind, I base this supposition on the fact that there were other instances in which Angélique de Saint-Jean discussed with friends outside the convent the possibility of publishing the nuns' writings. For example, see her letter to Mme de Fontpertuis quoted in F. Ellen Weaver, Madame de Fontpertuis: Une dévote janséniste, amie et gérante d'Antoine Arnauld et de Port-Royal (Paris, 1998), p. 125. I wish to thank Ellen Weaver for helping me in my efforts to locate the original manuscripts of the three interrogation reports.

${ }^{27}$ The quarrel around the Augustinus itself can be traced back to the struggles between the Jesuits and the Dominicans in the sixteenth century; see Antoine Adam, $D u$ mysticisme à la révolte: Les jansénistes du XVII siècle (Paris, 1968), pp. 53-57.

${ }^{28}$ Ibid., p. 84.

${ }^{29}$ Antoine Arnauld, "Considérations sur l'entreprise de M. Cornet," in Oeuvres de Messire Antoine Arnauld, docteur de la maison et société de Sorbonne, 41 vols. (Paris, 1755-83), 19:34 (hereafter abbreviated as Oeuvres de M. Arnauld). And see Sedgwick, Jansenism (n. 6 above), p. 56.

${ }^{30}$ Lucien Ceyssens, "Les cinq propositions de Jansenius à Rome," Revue d'histoire ecclésiastique 66 (1971): 449-501. Mazarin was the driving force behind the publication of this bull in France; see Sedgwick, Jansenism, p. 68. 
in Jansen's text. This critique made a distinction between "right" and "fact" (droit and fait), by asserting the church's right to rule on matters of doctrine but denying its authority over matters of fact (the fact being whether or not Jansen's text contained the heretical doctrine). The same doctors at the Sorbonne who had condemned the Augustinus now turned against Arnauld and had him expelled from the theology faculty in 1655 on the grounds of presumption (témérité) for challenging the papal decision. ${ }^{31}$ Coinciding with the political upheaval of the Fronde, the conflict at the Sorbonne prompted the regency government to regard Jansen's supporters, many of whom were also supporters of Cardinal de Retz (archbishop of Paris, 1654-62) as factious agitators set out to undermine the French church from within. ${ }^{32}$ When Louis XIV came to power in 1661, he maintained the regency government's profound animosity toward the so-called Jansenists and, with the encouragement of his Jesuit confessors, made it his priority to drive them out of France. ${ }^{33} \mathrm{He}$ turned to a council of select bishops, who drew up and circulated a formula for a formal condemnation of the five propositions allegedly drawn from the $\mathrm{Au}$ gustinus and denounced by Rome to be signed by all members of the French clergy.

When the Jansenists learned of Louis XIV's demand that they sign the formula, a debate arose among them over how to sign, since most of them believed that Jansen's text contained the true doctrine of Augustine. ${ }^{34}$ Some argued that a signature was necessary - regardless of any doubts an individual

${ }^{31}$ Jacques Gres-Gayer, Le jansénisme en Sorbonne, 1643-1656 (Paris, 1996), pp. 149-50.

${ }^{32}$ Richard M. Golden, The Godly Rebellion: Parisian Curés and the Religious Fronde, 1652-1662 (Chapel Hill, N.C., 1981), pp. 26-27. Retz had been the leader of a noble faction that tried to overthrow the government during the Fronde. Even after the nobles' rebellions ended, the monarchy continued to fear Retz for his ability to foment disorder among the Parisian people and considered him to be its most dangerous internal threat.

${ }^{33}$ The Jesuit priest François Annat and Bishop Pierre de Marca in particular were driving forces behind Louis XIV's campaign against Jansenism; Adam, p. 243. The term "Jansenist" is problematic because it was first coined by the enemies of Jansen to assert that he and his followers formed a cabal to undermine the church. Jansen's apologists denied the existence of such a plot and called Jansenism itself a "phantom." In spite of these early efforts to abolish the terms "Jansenism" and "Jansenist," they remained in common use as convenient labels for all those who sympathized with Jansen. Nevertheless, historians continue to grapple with the terms because of the wide range of theological and political differences among these sympathizers; see Lucien Ceyssens, "Que penser finalement de l'histoire du jansénisme et de l'antijansénisme?" Revue d'histoire ecclésiastique 88 (1993): 108-30. In this article, I use the term "Jansenist" interchangeably with the term "Port Royalist" to denote the circle of friends and supporters of the Port Royal nuns.

${ }^{34}$ E. J. Kremer, "Grace and Free Will in Arnauld," in The Great Arnauld and Some of His Philosophical Correspondents, ed. E. J. Kremer (Toronto, 1994), pp. 219-39. 


\section{Kostroun}

might harbor - in the name of church unity. Others argued that any signature would entail a formal denunciation of Augustine and should be refused outright with a written explanation of opposition. ${ }^{35}$ Still others - most notably, Antoine Arnauld - sought a compromise by attaching a heading to their signatures containing Arnauld's famous right/fact distinction. Those who signed with this added clause agreed to denounce the doctrine condemned by the bulls with "heart and mouth" but requested the right to remain respectfully silent on the question of whether or not the five propositions and the heretical doctrine they contained actually appeared in Jansen's text. ${ }^{36}$

The debate among Jansenists over how to sign intensified when Louis XIV began pressuring the vicars-general of Cardinal de Retz to extract signatures from the Port Royal nuns. For over twenty years, Port Royal's supporters had persistently defended the nuns against accusations in anti-Jansenist pamphlet literature that Port Royal was a "seminary for heresy." 37 These supporters argued that the nuns should be left out of the debate because, as women, they could not possibly be responsible for the doctrine attributed to their male superiors. ${ }^{38}$ But now the formula made it impossible to avoid involving the nuns in the wider conflict, and the debate among Jansenists shifted to the question of how the nuns should respond. The answer to this question was not obvious, because of the political implications of Louis XIV's request. Ever since Louis XIV arrested Cardinal de Retz in 1652, he had been seeking ways to gain control over the diocese of Paris. ${ }^{39}$ In the eyes of the Port Royalists, the king's command that the nuns give their signatures was just another politically opportunistic maneuver that would allow him to violate the cardinal's rightful jurisdiction over the nuns while posing as a defender of the faith..$^{40}$ The political concerns hanging over the nuns' signatures put them in a difficult position, because as a matter of conscience they did not want to sign. But if they refused to sign, they would give Louis XIV the excuse he needed for further royal trespassing. As supporters both of Jansen's orthodoxy and Cardinal de Retz's

\footnotetext{
${ }^{35}$ Godefroi Hermant, Mémoires de Godefroi Hermant sur l'histoire ecclésiastique du XVII siècle (1630-1652), 6 vols. (Paris, 1905), 5:49. Abbé le Roy was the leading advocate of refusing all signatures: Gérard Namer, L'Abbé le Roy et ses amis: Essai sur le jansénisme éxtrémiste intramondin (Paris, 1964).

${ }^{36}$ Sedgwick, Jansenism, pp. 108-10.

${ }^{37}$ Attacks against Port Royal's orthodoxy first began with the debate over the Chapelet Secret, a devotional piece composed by the nun Agnès Arnauld (sister of Angélique and Antoine Arnauld) and circulated by her confessors in 1633. See Jean-Robert Armogathe, "Le Chapelet Secret de Mère Agnès Arnauld," XVIIe Siècle 70, no. 1 (1991): 77-86.

${ }^{38}$ Antoine Arnauld, "Seconde lettre à un duc et pair," in Oeuvres de M. Arnauld (see n. 29 above), 19:424-28.

${ }^{39}$ Golden, pp. $18-68$

${ }^{40}$ Hermant, 4:695.
} 
jurisdiction over the diocese of Paris, the nuns could not stand up for one cause without jeopardizing the other.

The nuns participated in this debate by having their confessor, Claude de Sainte-Marthe, pose the question to their supporters of whether or not they needed to understand Jansen's text in order to sign the formula. This was the most important question for them because, without having read the text, the nuns could not know for sure whether the formula condemned Jansen's actual interpretation of Augustinian doctrine or not. Although they were not claiming a right to read the Augustinus, the nuns did not wish to sign the formula in ignorance either. As Sainte-Marthe argued, if ignorance absolved them from the potential for sin should they obey the king and sign the formula, then "[ignorance] would deprive us of the means to suffer for the truth, which is what every Christian should love more than anything else in the world." ${ }_{41}$ Sainte-Marthe's comments were dismissed by some Jansenists who believed that the nuns should sign the formula without question because it was their primary duty as women to obey their male superiors. ${ }^{42}$ Antoine Arnauld again sought a compromise by drawing up a special heading for the nuns to use when signing that stated that they "espouse absolutely and without reserve the faith of the Catholic Church, and ... they condemn all that it condemns."43 While this clause sounded straightforward enough, one can detect traces of the right/fact distinction in its mental reservations. By mentioning the nuns' faith only, it implies their silence on the question of fact.

Retz's vicars-general, themselves supporters of Jansen, allowed the nuns to sign the formula with this heading, which most of them did without question. However, just as there was disagreement among male Jansenists, there was disagreement among the nuns as well. In particular, Jacqueline Pascal (Blaise Pascal's sister), wrote a letter directed to Antoine Arnauld in the summer of 1661 denouncing his heading because she believed that any signature would condemn the doctrine of Augustine. ${ }^{44}$ She criticized Arnauld's restrictive clause by stating that never before in the history of the church had the faithful "used fine distinctions" or "disguise and pretense" to defend the truth. ${ }^{45}$ She

${ }^{41}$ Hermant, 5:85.

${ }^{42}$ This was the position of Martin de Barcos, the abbot of Saint-Cyran; see Martin de Barcos, Correspondance de Martin de Barcos, abbé de Saint-Cyran, avec les abbesses de Port-Royal et les principaux personnages du groupe janséniste, ed. Lucien Goldmann (Paris, 1956).

${ }^{43}$ Antoine Arnauld, "Apologie pour les Religieuses de Port Royal," in Oeuvres de M. Arnauld, 23:317-18.

${ }^{44}$ Jacqueline Pascal addressed the letter to her fellow nun Angélique de Saint-Jean (Antoine Arnauld's niece), but she asked Angélique de Saint-Jean to forward the letter to her uncle.

${ }^{45}$ Jacqueline Pascal, "Lettre à la soeur Angélique de Saint-Jean,” June 23, 1661, in 


\section{Kostroun}

wrote that she would rather "pray God to allow us to die today" than "to allow such an abomination to occur inside his church." 46 As for the consensus among male Jansenists that the nuns should have no part of the formula controversy, she wrote: "I know very well that people say that nuns are not meant to defend the truth, although, one could say, due to an unfortunate course of events and the moral upheaval in which we now find ourselves, that for as long as bishops act with the courage of nuns, then nuns must act with the courage of bishops. If we are not meant to defend the truth, then we are meant to die for the truth." ${ }^{47}$ She then supported her bold position by citing Saint Bernard and the abbé of Saint-Cyran, by making an analogy between the formula and a hypothetical case involving Augustine, and by proposing her own heading for the formula. ${ }^{48}$

Two things become clear when we read Pascal's letter. First, in spite of the church's ruling on female ignorance in matters of theology, some of the Port Royal nuns were well versed in the theological issues at stake. ${ }^{49}$ Second, some nuns felt that they had a special mission to set an example for their male counterparts within the church. Pascal certainly saw male ecclesiastics as turning the formula crisis into an opportunity for political maneuvering. She believed that it was now up to the nuns to use every resource they had, both physical and intellectual, to bring the debate back to the fundamental question of truth or error. Her emphasis on bodily sacrifice reminds us that the Jansenist quarrel was a battle of the pen, not the sword, and that Louis XIV's request for their signatures involved a new kind of obedience, one that demanded internal adherence to a list of propositions, not just external signs of submission. Because women were asked to sign the formula equally with men, this

Blaise Pascal, Oeuvres complètes, ed. Michel Le Guern, 2 vols. (Paris: Gallimard, 1998), 1:36. The letters of Jacqueline Pascal as well as those of other family members are included in this volume of complete works. According to the editor, this helps the reader "to better situate Pascal between the reality and the legend" (Michel Le Guern, "Note sur la présente Edition," in Pascal, Oeuvres complètes, 1:xlv).

${ }^{46}$ Pascal, "Lettre," p. 37.

${ }^{47}$ Ibid., p. 39: “Je sçais bien qu'on dit que ce n'est pas à des filles à défendre la vérité; quoiqu'on peut dire, par une triste rencontre du temps et du renversement où nous sommes, que puisque les évêques ont des courages de filles, les filles doivent avoir des courages d'évêques. Mais si ce n'est pas à nous à défendre la vérité, c'est à nous à mourir pour la vérité."

${ }^{48}$ Ibid., pp. 1:39-41; 1087-89. Her choice for citations reflects texts that were considered appropriate reading for nuns: the lives of the saints, the church fathers, and the sermons of their confessors.

${ }^{49}$ The question of the nuns' erudition was always a delicate point for Port Royal's supporters. In the case of Jacqueline Pascal, for example, Arnauld explained in his writings that she had entered the religious life at a late age and had learned about the Jansenist theological controversies before becoming a nun: Arnauld, "Apologie pour les Religieuses de Port Royal," p. 310. See also Bernard Chédozeau, "Idéal intellectual et vie monastique à Port-Royal,” Chroniques de Port Royal (1988), pp. 57-74. 
new command for obedience ignored all bodily difference between the sexes. By interjecting the female body as a target for violence, Pascal was reclaiming a feminist position from the querelle des femmes of the previous two centuries. ${ }^{50}$ During this querelle, feminists such as Christine de Pisan (1365-1429) countered misogyny by claiming that God favored women by privileging their bodies as sites for redemptive pain and suffering..$^{51}$ In addition to claiming this position of female spiritual superiority, Pascal also aligned herself with the literary and cultural ideal of the femmes fortes ("strong women") that emerged from the querelle des femmes and frequently appeared in publications in the first half of the seventeenth century. ${ }^{52}$ The femmes fortes were ambiguous, androgynous figures who stepped forward to lead their communities in times of crisis. Their heroism was typically attributed to their chastity and to their desire for liberty above all other advantages and comforts that they may have previously enjoyed or derived from remaining subservient. ${ }^{53}$

Pascal's recourse to feminist arguments from the querelle des femmes is significant, considering that she wrote at a time when feminist writers had already abandoned these feminine cultural ideals in favor of new ones. By the mid-seventeenth century, the femme forte had been replaced by the précieuse, a highly educated women who was respected for her social grace and literary refinement. ${ }^{54}$ With this shift in cultural ideals came a corresponding transformation in feminist debates from an emphasis on women's heroism and virtue to one on the equality of the sexes in the realms of reason, education, and marriage. On the one hand, the Port Royal nuns supported many of the principles of this new feminism, as they clearly valued such things as a woman's access to education, her natural capacity for reason, and her autonomy in the

${ }^{50}$ Joan Kelly, "Early Feminist Theory and the Querelle des Femmes, 1400-1789," in Women, History, and Theory: The Essays of Joan Kelly (Chicago, 1984), pp. 65109.

${ }^{51}$ Jordan (n. 15 above), pp. 114-15.

${ }^{52}$ Maclean (n. 23 above), pp. 64-87; Joan E. DeJean, Tender Geographies: Women and the Origins of the Novel in France (New York, 1991), pp. 33-42; Danielle HaaseDubosc, Ravie et enlevée: De l'enlèvement des femmes comme stratégie matrimoniale au XVIIe siècle (Paris, 1999), pp. 18-20. These scholars all agree that although literary portraits of the femmes fortes provided powerful images of female strength, initiative, and agency, they left behind an ambiguous legacy. These women were marvelous and notable precisely because they did not fit into the norm. They were not meant to be pioneers of sustained structural change but, rather, objects of wonder or admiration. Haase-Dubosc, however, links the femmes fortes to structural changes in attitudes by arguing that their love of liberty, a theme that she examines in narratives of marital abductions, prepared the foundation for discourses on the equality of the sexes in the latter half of the century: Haase-Dubosc, p. 323.

${ }^{53}$ Maclean, pp. 71, 83.

${ }^{54}$ DeJean, p. 51; Linda Timmermans, L'accès des femmes à la culture (1597-1715) (Paris, 1993), pp. 97-122. 


\section{Kostroun}

decision to take vows. ${ }^{55}$ On the other hand, in the formula crisis the nuns found themselves at odds with this trend toward sexual equality. Louis XIV's command for both men's and women's signatures implicitly exploited the principle of sexual equality for his own political purposes. Consequently, Jacqueline Pascal resorted to earlier feminist arguments grounded in sexual difference because, in this case, the value of sexual equality had become compatible with Louis XIV's mission to exert greater control over individual conscience. ${ }^{56}$

Pascal's radical opposition made her an exception among the nuns in the summer of 1661. But when Louis XIV intensified his pressure on them by refusing to accept their signatures with Arnauld's heading, the community adopted her spirit of resistance in self-defense. ${ }^{57}$ Soon after signing the formula, the nuns received notice that their signatures had been ruled illegitimate and that the king was ordering them to sign again, this time without any restrictive clause. Upon learning this news, Port Royal's abbess, Agnès Arnauld (the late Angélique Arnauld's younger sister), wrote to her brother Antoine requesting a new heading for their signatures, one that would refuse the king's order by insisting more explicitly upon their silence on the question of fact. ${ }^{58}$ The heading Antoine Arnauld proposed this time began with the phrase: "Considering our ignorance of those matters that are above our profession and our sex, the most we can do is give witness to the purity of our faith." ${ }^{59}$ As in his previous heading for the nuns, Arnauld mentions only their faith and implies their silence on the question of fact. This time, however, he stresses their

\footnotetext{
${ }^{55}$ Chédozeau, pp. 64-72. At first glance, the spiritual writings at Port Royal seem to conform to the dominant anti-intellectualism in French spirituality at this time by espousing such things as the limited role of the intellect in prayer. However, Port Royal also contradicted the norm by emphasizing individual self-reflection and by setting aside thirty minutes a day for the nuns to engage in individual reading. As for the convent's emphasis on personal vocation as a prerequisite for joining the convent, see Arnauld, "Apologie pour les Religieuses de Port Royal," pp. 179-81.

${ }^{56}$ The alliance between discourses on sexual equality and Louis XIV's efforts to exert greater control over his subjects seems to confirm Siep Stuurman's observation that feminist thought in the second half of the century had become compatible with the state's civilizing process: Stuurman, "Literary Feminism" (n. 23 above), p. 24. On the civilizing process as a means for greater social control under Louis XIV, see Norbert Elias, The Court Society, trans. Edmund Jephcott (New York, 1969).

${ }^{57}$ Jacqueline Pascal died in October 1661, just a few months after the nuns signed the first mandement. The Port Royalists called her "the first victim of the signature" as they attributed her death to the extreme pain and chagrin caused to her by the formula crisis: Arnauld, "Apologie pour les Religieuses de Port Royal," p. 324.

${ }^{58}$ The nuns' initiative in this process is evident in Angélique de Saint-Jean Arnauld d'Andilly's letter of November 9, 1661. In this letter, she compares the nuns to the "retainers of the princes of the Army of Ahab": reprinted in Hermant (n. 35 above), $5: 345$.

${ }^{59}$ Arnauld, “Apologie pour les Religieuses de Port Royal,” p. 330.
} 
silence by alluding to the church laws prohibiting women from studying theology. By signing with this restrictive clause, the nuns openly rejected Louis XIV's command for a simple signature. More important, the clause implicitly attacked Louis XIV's command as an illegitimate use of authority by claiming that they owed obedience to a higher rule, to the church law that imposed silence on women in matters of theology.

When the abbess received Arnauld's new heading, she gave a speech to the community in which she explained that "women of conscience" should sign under this heading because there were two questions at stake..$^{60}$ The first, she said, was the question of whether the five propositions were good or bad, "Catholic or heretical." Regarding the question of orthodoxy, she told them: "We are obligated to submit to ecclesiastical authority as humble daughters of the church." ${ }^{61}$ As for the second question at stake, she explained that this involved a judgment over whether or not the five propositions appeared in Jansen's book in the sense in which they were condemned. This judgment, she told them, was at the heart of the problem, because "many virtuous people insist that they [the five propositions] do not appear in this book." ${ }^{22}$ She advised the nuns not to sign in regard to this matter of fact, because if theologians themselves disagreed over it, there was surely no way for the nuns to know the truth since they were not trained in theology. Because the nuns could never know the truth for themselves, it was most prudent for them to remain silentfor if they signed in error, they would be guilty of a false witness.

The abbess's speech outlined the three elements that formed the basis of the nuns' resistance from that point on. The first was the adoption of a strict position on feminine obedience. By calling her nuns "women of conscience," the abbess reminded them of Port Royal's tradition of perfect obedience to the rules and demands of the religious life. This tradition was forged by Angélique Arnauld, who, following the example of Teresa of Avila, fashioned herself into a model of feminine obedience and Christlike humility in order to reform her convent according to the Rule of Saint Benedict and the decrees of the Council of Trent. ${ }^{63}$ This strict position on feminine obedience was also reflected in their heading's words "above our profession and our sex," which indicated their

${ }^{60}$ Agnès Arnauld, in Relation de ce qui s'est passé à Port Royal depuis le commencement d'Avril 1661 jusqu'au 27 du même mois de l'année suivante . . . , in Divers actes (n. 1 above), pp. 25-28.

${ }^{61}$ Ibid., p. 25: "Nous sommes obligées de nous soumettre a l'autorité Ecclésiastique, comme étant humbles filles de l'Eglise."

${ }^{62}$ Ibid.: "Plusieurs gens de bien assurent qu'elles ne sont point dans ce livre."

${ }^{63}$ For an account of Angélique's self-abnegation and reform, see Louis Cognet, $\mathrm{La}$ réforme de Port-Royal, 1591-1618 (Paris, 1950), pp. 145-56. On the influence of Teresa of Avila at Port Royal, see F. Ellen Weaver, The Evolution of the Reform of PortRoyal: From the Rule of Citeaux to Jansenism (Paris, 1978), p. 127. 


\section{Kostroun}

desire to adopt a literal interpretation of church laws on women. The phrase also reveals the second element of the nuns' resistance: the use of legalistic arguments regarding the rights and jurisdiction of women within the church. By emphasizing their right to resist the king on the grounds of the particular obligations of their corporate identity, or order, the heading's preliminary phrase follows a basic premise of traditional parlementaire legal theory. ${ }^{64}$ The final element of the nuns' resistance was the belief that, although they were technically ignorant of theology, the nuns were nevertheless bound by their capacity for reason to refuse the formula. As the abbess explained in her speech, the nuns could see that learned theologians differed over the interpretation of the Augustinus. Judging from these differences, the nuns could reasonably surmise that a signature on their part - a taking of sides in the debate-might constitute an error. Because of this potential for error, the abbess advised them to remain silent on the matter of fact, because the command for female silence was the one command that they could know for certain. The practice of subjecting religious decisions to the judgment of reason was not unique to the nuns but was typical of a growing trend in religious polemic developing across Europe at this time. ${ }^{65}$

These three elements-feminine obedience, the defense of jurisdictional privilege, and the authority of reason to determine religious orthodoxy - were all part of a larger discourse on the nature of legitimate authority that preoccupied political debate in the seventeenth century. Anchoring their resistance in these broader political issues strengthened the nuns' opposition to Louis XIV by bringing home its significance to all who were concerned with French politics, not just those with Jansenist sympathies. In addition, by refusing to sign the formula on the grounds of sexual difference, they also anchored the right/fact distinction to the notion of "natural" feminine weakness. From this point on, the nuns no longer sought to compromise with the formula; they attacked its very legitimacy by claiming that it violated the natural order of gender.

\footnotetext{
${ }^{64}$ Compare, e.g., Antoine Arnauld's heading with Avocat-Général Omar Talon's preamble to a royal declaration reviewed by the Parlement in 1648. Talon wrote, "The opposition of our votes, the respectful resistance which we bring to bear in public affairs must not be interpreted as disobedience but rather as a necessary result of the exercise of our office and of the fulfilling of our obligations" (quoted in J. H. Shennan, The Parlement of Paris [Ithaca, N.Y., 1968], p. 268). The nuns' request for respectful silence on the matter of fact and Talon's request for "respectful resistance" are both justified on the grounds of the necessity for their dutiful fulfillment of office.

${ }^{65}$ Susan Rosa, "Seventeenth-Century Catholic Polemic and the Rise of Cultural Rationalism: An Example from the Empire," Journal of the History of Ideas (1996), pp. $87-107$.
} 


\section{The Doctrine of "Human Faith" AND the Three InTERrogations}

The nuns' signatures with the second heading in the spring of 1664 had its expected provocative effect. Cardinal de Retz's abdication from the archbishopric of Paris in February 1662 had opened the way for Louis XIV to handpick a supporter who would better enforce his policies in the archdiocese. ${ }^{66}$ When Louis XIV appointed Hardouin de Péréfixe in April 1664, Péréfixe made it his priority to extract a signature "pure and simple" from the nuns. ${ }^{67}$ Péréfixe drew up a new mandement (episcopal letter) for the nuns, one that demanded their signature with no reservation. This mandement differed from the earlier ones presented to the nuns in its inclusion of a clause requesting that the nuns sign the matter of fact out of "human faith." The doctrine of human faith was the archbishop's attempt to undercut the nuns' claim that they had to remain silent on the matter of fact because of their "natural" theological ignorance. When Péréfixe presented his mandement to the nuns that June, he explained that, given their ignorance, he was not asking for their signatures as a sign of their internal belief but only as a sign of their obedience to his authority. He claimed that he would answer to God on their behalf for any possible error that they might incur in signing the formula. Although Péréfixe assured the nuns that their signatures would reflect a matter of discipline and not faith, the nuns refused to see it this way. Instead, they interpreted Péréfixe's command to obey male superiors - that is, the ordained custodians of church law - rather than the laws themselves as an assault on their right to conscience and their spiritual equality before God. From their perspective, Péréfixe had pushed their claim to ignorance to a logical conclusion that they had neither foreseen nor desired. This dilemma created a new paradox for the nuns, who now had to insist upon their "natural" ignorance while simultaneously demonstrating that they had sufficient intelligence to doubt the formula. The doctrine of human faith, therefore, changed the formula debate dramatically: from this point on, the nuns were not just opposing the formula; they were defending their spiritual equality with men before God. ${ }^{68}$

${ }^{66}$ Cardinal de Retz's settlement with Louis XIV, in which he exchanged his archbishopric for several less prestigious yet equally lucrative benefices, was viewed as a betrayal by many of his Jansenist supporters: Hermant, 5:443.

${ }^{67}$ Two years elapsed between the abdication of Cardinal de Retz and Péréfixe's appointment to the archbishopric, because of the untimely death of Retz's successor, Pierre de Marca, in 1662 and a diplomatic crisis between France and Rome. During the "affair of the Corsican guards" the pope refused to confirm any of Louis XIV's appointments to ecclesiastical office: Andrew Lossky, Louis XIV and the French Monarchy (New Brunswick, N.J., 1994), pp. 120-21.

${ }^{68}$ The doctrine of human faith was also interpreted by Port Royal's defenders as 


\section{Kostroun}

Péréfixe published his mandement on June 8,1664, and traveled to Port Royal two days later day for a pastoral visit. His trip was no ordinary visit, however, as his purpose was to pressure the nuns to sign the formula out of human faith. We know the details of Péréfixe's visit from a series of reports composed by the nuns. ${ }^{69}$ According to the nuns' records, Péréfixe arrived at Port Royal de Paris at 6:30 in the morning on June 10, 1664, accompanied by one of his vicars-general. He began his visit by saying Mass and by delivering a speech to the community in which he preached obedience and recounted how Jansen's text had been condemned by Rome. ${ }^{70}$ Next, he began the scrutin, a customary series of confessions, with each nun to discuss her grievances or concerns regarding the convent. In this instance, however, the scrutin provided Péréfixe with an opportunity to coerce each nun privately to sign the formula. Convent records state that the archbishop met with all eighty-seven of the nuns over the course of several days, but we have the nuns' transcripts for only three of these interviews. These are the reports of Gertrude Dupré, Angélique de Saint-Jean Arnauld d'Andilly, and Christine Briquet, to which we will now turn our attention.

$* * *$

The interrogation reports of Dupré, Arnauld d'Andilly, and Briquet provide us with a small sample of what the Port Royal nuns wrote, edited, and circulated among their supporters throughout the decade of the formula crisis. The act of writing was an important feature of their resistance, because no outside witnesses were allowed into the convent to monitor the archbishop. The nuns' journal, therefore, with its careful and detailed entries, provided the nuns' supporters with the crucial evidence needed to formulate their defense in ecclesiastical and civil courts and in the realm of public opinion. At the time of

setting a precedent for Jesuit theories of papal infallibility that granted the pope authority over all judgments both in the matter of theology and in discipline. The fear that the doctrine of human faith was merely that of papal infallibility in disguise prompted many - most notably, Pierre Nicole - to publish pamphlets denouncing this doctrine: Tetsuya Shiokawa, "Logique et politique: Le rôle de la notion de foi humaine dans l'affaire de la signature du formulaire," in Force et justice dans la politique de Pascal, ed. Christian Lazzeri (Paris, 1993), pp. 307-15.

${ }^{69}$ This practice of keeping detailed records of all of their exchanges with their superiors began in 1659, at the time when Louis XIV first ordered the expulsion of all postulants and pensioners from Port Royal; see Weaver, "Port Royal" (n. 11 above), p. 1938.

${ }^{70}$ The community of religious at Port Royal de Paris enclosed sixty-three nuns, while the other branch of the house, Port Royal des Champs, enclosed twenty-four nuns. Péréfixe visited both houses in June 1664, repeating at Champs the same procedure he followed in Paris. See Jérôme Besoigne, Histoire de l'abbaye de Port-Royal, 6 vols. (Cologne, 1752 [Geneva, 1970]), I: vi: 485. 
the formula crisis, many of the nuns' journals, letters, and procès verbaux circulated outside the convent in manuscript form. Sometimes these writings found their way into print in the form of short leaflets (factums) or as excerpts in larger apologetic texts. ${ }^{71}$

It is not clear at what time and in what form these three interrogation reports first circulated, but they were probably composed in the summer of 1664 with eventual publication in mind. Evidence of the nuns' intent to publish lies in the form of the interrogation reports themselves. Although the authors present these reports as faithful transcriptions - that is, as products of spontaneous, antirhetorical sincerity (a quality seen as the characteristic of female writing at the time) - they nevertheless display the nuns' tremendous wit and literary skill. ${ }^{72}$ In each of these reports, the nuns adopt an innocent, naive, or extremely earnest tone in their dialogues to discredit and humiliate Archbishop Péréfixe. The skill shown in these texts has already been noted by the nineteenth-century literary critic Charles-Augustin de Sainte Beuve, who compared their writings to comedic episodes in the writings of Ariosto. ${ }^{73}$ A more likely candidate for comparison, however, is Teresa of Avila, another witty and skillful writer, whose work we know the Port Royal nuns to have both read and admired. ${ }^{74}$ In addition, considering that behind their assumed innocence and credulity the nuns were taking aim at Péréfixe's casuistic doctrine of human faith, we might also compare these texts to the fictional dialogues in Blaise Pascal's Provincial Letters. $^{75}$

The full rhetorical and literary skill of these interviews is apparent only when we recognize how the nuns tapped into contemporary cultural and political discourses to give their resistance broad public relevance. These were the discourses of feminine obedience, rationality, and order, which, as seen above in Agnès Arnauld's speech, formed the cornerstones of the nuns' resis-

${ }^{71}$ Louis Cognet, introduction and notes to Relation de la captivité (n. 26 above).

${ }^{72}$ The paradox of the nuns' literary skill and their claim that they were merely reporting on an event was typical for the period. For example, women excelled in the epistolary genre at this time precisely because of the common belief that they were naturally naive in the literary arts: Michèle Longino Farrell, Performing Motherhood: The Sévigné Correspondence (Hanover, N.H., 1991), pp. 29-36.

${ }^{73}$ Charles-Augustin de Sainte-Beuve, Port-Royal, ed. Maxime Leroy, 3 vols. (184061; Paris, 1954-55), 2:665.

${ }^{74}$ Angélique Arnauld's (and Antoine Arnauld's) older brother Robert Arnauld d'Andilly translated Teresa of Avila's writings into French for the nuns. Her writings, especially the Book of Foundations, display a similar brand of humor under the guise of artless skill and feminine affectivity; see Alison Weber, Teresa of Avila and the Rhetoric of Femininity (Princeton, N.J., 1990), pp. 9-10, 128-34.

${ }^{75}$ I want to thank Susan Rosa for pointing me, in her comments to my paper presented at the annual meeting of the Catholic Historical Association in 2001, to Pascal's Provincial Letters as a potential text for comparison to the nuns' interrogations. 


\section{Kostroun}

tance. Although each interrogation contains a mixture of these discourses, there is a tendency by each nun to emphasize one discourse over another. These differences support the individual nuns' claims to authorship, as they reflect distinct preferences for certain literary styles and modes of argumentation. However, we also know that Angélique de Saint-Jean Arnauld d'Andilly revised, edited, and prepared Port Royal's manuscripts for posterity and that virtually every record emanating from Port Royal before her death in 1684 bears her mark. ${ }^{76}$ Considering that these three interrogation reports appear to be the only written legacy of Péréfixe's scrutin in June 1664, and that they were published together in 1724, they can be read as inviting a publishing strategy in which the three parts would be brought together to form one integrated whole.

\section{GERTRUde DupRÉ: OBEDIENCE}

The first of the nuns to be interviewed by Péréfixe on June 10, 1664, was Marguerite de Sainte-Gertrude Dupré. Originally a nun in Flanders, Dupré transferred to Port Royal after learning about Angélique Arnauld's reform from Jansen himself. ${ }^{77}$ Although Dupré shows herself in this report to be firm in her resistance to the archbishop, she ended up with a reputation for fickleness, as she was the first of the Port Royal nuns to sign the formula under exile. Even though she retracted this signature, she soon signed and retracted once again. When she finally joined her fellow nuns under house arrest at Port Royal des Champs in the spring of 1665 , she was able to sustain her opposition to the end. She contracted a deadly fever in July 1665 and died without the sacraments due to the archbishop's prohibition. ${ }^{78}$

Duprés report is the shortest of the three, beginning with a brief description of her initial meeting with the archbishop and then immediately launching into a transcript of their conversation in the form of a dialogue. As we saw at the opening of this article, Dupré's interview took a turn for the worse almost immediately. As soon as she began to explain that her conscience prohibited her from signing the formula, Péréfixe interrupted her sarcastically to ask if it was her conscience that prohibited her from obeying her archbishop. The remaining interview hinged on this conflict between his command for obedience out of "human faith" and her response that she could obey him only insofar as this definition of obedience conformed to higher, divine laws. For example,

${ }^{76}$ F. Ellen Weaver, "Angélique de Saint-Jean: Abbesse et 'mythographe' de PortRoyal," Chroniques de Port-Royal 34 (1985): 93-108.

${ }^{77}$ Besoigne, 2: viii: 203.

${ }^{78}$ Ibid., p. 334. 
at one point he remonstrated with her: "Listen to me, I beg you, answer me precisely for that which I ask of you and don't try to evade me: can you not sign after I, your archbishop and one whom you must obey, command you to do it?"79 To this question, Dupré answered, "No, Monsignor, I cannot." When he asked for her reasons, she answered, "Monsignor, ... I cannot give witness ... in the face of God and all of the church against an innocent person; this would go directly against God's commandment that prohibits us from giving false testimony against our neighbor." ${ }^{80}$ As we see in this passage, when Péréfixe commanded her obedience out of human faith, she refused him by claiming that his order would force her to violate God's basic command against bearing false witness.

Dupré further emphasized her obedience to God above Péréfixe by stressing that the situation pained her and that she needed God's help. When Péréfixe berated her for her resistance, she responded that the nuns were doing all they could to obey him and that it was only in the case of the formula that they had failed: "But, Monsignor, is it to fail in obedience, even though we are disposed to fulfill with respect and submission all that it pleases you to command us, and even though we are as afflicted as we are to not be able to satisfy you in this one point? For a long time we have been praying God to inspire you." 81 Her words had no effect, as he responded, "And to inspire what? To fulfill your will?" He then proceeded to explain that those lacking in obedience on this one point were lacking in all, because "when the pope has ruled and the church has concurred, we must obey him." ${ }^{82}$ In his mind, her appeal to a higher authority was nothing short of stubbornness and pride.

As Dupré continued to insist on the pain she suffered from her inability to obey him, Péréfixe grew more and more frustrated, and his outbursts and insults increased. At one point, when he tried to convince her to sign by naming others who had signed, he included the name of the priest who had professed

${ }^{79}$ Dupré (n. 1 above), p. 15: "Écoutez-moi je vous prie, repondez-moi précisément à ce que je vous demande et ne m'allez point faire de détours: ne pouvez-vous pas signer après que moi qui suis votre archevêque et a qui vous devez obéir, vous le commande?"

${ }^{80}$ Ibid.: "Non, Monseigneur, je ne le puis"; "Monseigneur ... je ne puis pas rendre un témoignage ... à la face de Dieu et de toute l'église contre une personne innocente, ce qui seroit directement contre le commandement de Dieu qui nous défend de rendre un faux témoignage contre notre prochain."

${ }^{81}$ Ibid.: "Mais, Monseigneur, est-ce manquer d'obéissance, lorsque nous sommes disposées à accomplir avec respect et soumission tout ce qu'il vous plaira nous commander, et que nous sommes aussi affligées que nous les sommes de ne pouvoir vous satisfaire dans le seul point dont il s'agit."

${ }^{82}$ Ibid.: "Et quoi inspirer? De faire votre volonté?"; “. . . quand le pape en a défini, que l’Église y a passé on doit lui obéir." 


\section{Kostroun}

Dupré as a nun. When Dupré heard this name, she exclaimed: "Oh! Monsignor, it saddens me, and God knows the prayers that I make continually for him." ${ }^{83}$ Péréfixe shouted, "You are a stupid girl, and it's perfectly clear that you don't know what you are saying and that you are full of pride to judge such important persons in this way. Are you not the one who keeps quoting the Evangelist, 'Judge not lest ye be judged?'" ${ }^{44}$ Dupré wrote that he spoke so angrily that she fell to her knees and protested that it was not she. When he yelled that she should apply these words to herself, she responded, "But Monsignor, I am not judging anybody; you have commanded me in the name of God to speak simply and to tell you the truth, and that is what I have done.... I have told you what is in my heart." ${ }^{85} \mathrm{He}$ responded, "And I see it only too well, that you speak to me fully from the heart and that I do not complain about what you are saying, but about that which you have in the heart." ${ }^{\prime 6}$ She responded, "I am very upset ... to have upset you, but it is because I do not express myself well, because I do not judge anybody, and it is to avoid judging anybody that we do not participate in these debates that have nothing to do with us." ${ }^{87}$ Once again, he berated her: "You are stupid ... and you do not know what you say." He added, "in truth, I would not want to answer to God for my conscience if I were in your position." 88

The humor in this report derives from the discrepancy in power between Péréfixe and Dupré and the downward spiral caused by her repeated attempts to express herself under the pressure of his interruptions and escalating temper. As the interrogation progresses, the absurdity of the situation only increases as Dupré becomes increasingly awkward in her explanations at the same time that Péréfixe grows angrier with her. Eventually, Péréfixe's temper grows out of proportion, to the point that he seems to be fueling his own passions.

${ }^{83}$ Ibid., p. 16: “Oh! M[onseigneur] c'est ma douleur, et Dieu sçait les prières que je fais continuellement pour lui." The priest in question was Jacques de Sainte-Beuve (1613-1677).

${ }^{84}$ Ibid.: "Vous êtes une folle, on voit bien que vous ne sçavez ce que vous dites, et que vous êtes pleine d'orgueil, de juger ainsi des personnes si considérables. N'est-ce pas vous qui me citiez tantôt l'Evangile: Ne jugez point, et vous ne serez point jugez?'

${ }^{85}$ Ibid.: "Mais, M[onseigneur], je ne juge point, vous me commandez de la part de Dieu de parler simplement et de vous dire la vérité, je vous l'ai dite. . . je vous ai dit ce que j'avois dans le coeur."

${ }^{86}$ Ibid.: "Et je ne le vois que trop, que vous me parlez de l'abondance de vôtre coeur, et je ne me plains pas que vous me l'ayez dit, mais je me plains que vous l'ayez au coeur."

${ }^{87}$ Ibid.: "Je suis bien fâchée ... de vous avoir fâché; mais c'est que je ne m'exprime pas bien, car je ne juge de personne, et c'est pour ne point juger que nous ne prenons point de part dans toutes ces contestations qui ne nous regardent point."

${ }^{88}$ Ibid.: "Vous êtes une folle . . . vous ne sçavez ce que vous dites, et en vérité, je ne voudrois pas répondre de vôtre conscience en l'état où vous êtes." 
Underneath the humor in this report was a point of extreme importance to the Port Royal nuns: Péréfixe's definition of obedience was a false one and could not override their duty to obey their consciences. This privileging of conscience above human superiors was not a new strategy; it is as old as the Christian tradition itself. The nuns had a salient model for this strategy in Teresa of Avila. The Port Royalists professed a great admiration for Teresa of Avila, and there is much evidence to suggest that the "rhetoric of femininity" in Teresa's writing, a rhetoric that "strategically exploited certain stereotypes about women's character and language," influenced the Port Royal nuns in their own writings. ${ }^{89}$ Teresa's rhetoric arose out of her need to reconcile the paradoxes she faced as a woman having to fight male authorities in the name of monastic reform. ${ }^{90}$ Because Angélique Arnauld faced similar paradoxes half a century later while trying to reform Port Royal, it is not surprising that the accounts of her life adopt many of the rhetorical tactics present in Teresa's writings. For example, both women wrote "narratives of painful detachment" to describe the moments in which they pledged their lives to God against the wishes of their fathers. ${ }^{91}$ By describing these incidents as physically painful, these women acknowledged the gravity of their transgressions against paternal authority while simultaneously claiming that it was God who propelled them beyond their control. ${ }^{92}$

There was a link, therefore, between Dupré's expression of her painful inability to obey Péréfixe and the narrative strategies developed by Teresa of Avila a century earlier. This link was possible due to the legacy of Angélique Arnauld, who, like Teresa of Avila, manipulated common assumptions about femininity to assert her autonomy. The link to Teresa of Avila is significant because after her canonization, in 1622, she became a powerful authority for women religious to emulate. She provided a model for women of subverting male authority by manipulating the belief that while all Christians-both male and female-professed obedience to God, this obedience was more "natural" for women than men. Pitting the Teresian understanding of feminine obedience

${ }^{89}$ Weber (n. 74 above), p. 11.

${ }^{90}$ Ibid., p. 123.

${ }^{91}$ Ibid., p. 87. In her own case, Teresa wrote, "When I left my father's house I felt such dreadful distress that the pain of death itself cannot be worse": Teresa of Avila, The Life of Teresa of Avila by Herself, trans. J. M. Cohen (London, 1957), p. 33. Similarly, when Angélique rebelled against her father by enforcing Port Royal's cloister, the event was said to have caused "a violence against all of her nature" from which she never fully recovered: Angélique de Saint-Jean Arnauld d'Andilly, ed., Mémoires pour servir à l'histoire de Port Royal; et à la vie de la Révérende Mère Marie Angélique de Sainte-Magdeleine Arnauld, réformatrice de ce monastère, 3 vols. (Utrecht, 1742), 1:50.

${ }_{92}$ Weber, p. 87. 


\section{Kostroun}

against Péréfixe's command for total obedience to his authority, Dupré's report discredited Péréfixe by attributing her alleged disobedience to natural forces that were divinely ordered, painful, and beyond her control.

\section{ANGÉliQue de SAINT-JEAn ARnAUld D'AndiLly: REASON}

Dupré's interview ended in disaster, with her fleeing from the angry Péréfixe without even asking for a benediction. It is possible that Dupré's interrogation took place immediately before that of Angélique de Saint-Jean Arnauld d'Andilly, because when Angélique entered the room for her interview that same day, she noted that the archbishop was still visibly "heated and angry" from his exchange with the preceding nun. ${ }^{93}$ In spite of Péréfixe's initial bad temper, Angélique de Saint-Jean's interview progressed in a polite and congenial manner. The archbishop's relative politeness may have been the result of his greater respect for Angélique de Saint-Jean. As the daughter of Robert Arnauld d'Andilly and the niece of Antoine Arnauld and Angélique Arnauld, Angélique de Saint-Jean came from an important family and exercised considerable influence within the convent. She was raised at Port Royal by her aunts Angélique and Agnès Arnauld from a very young age and grew up to be the convent's primary chronicler or "mythographer." ${ }^{94}$ She, more than anybody else, was responsible for documenting Port Royal's past and shaping its traditions, especially its spirit of resistance. ${ }^{95}$ Péréfixe was probably aware that, of all the nuns at Port Royal, Angélique de Saint-Jean was his most important adversary. ${ }^{96}$

While Dupré's report may have drawn upon Teresa of Avila for its literary and rhetorical inspiration, Angélique de Saint-Jean Arnauld d'Andilly's report suggests the feminine ideal of her youth-that of the précieuse, the learned and refined woman. The précieuse came to dominate Parisian salons as a

\footnotetext{
${ }^{93}$ Angélique de Saint-Jean Arnauld d'Andilly, "Relation de ma Soeur Angélique de Saint-Jean," in Divers actes, lettres et relations (see n. 1 above), p. 20.

${ }^{94}$ Weaver, "Angélique de Saint-Jean: Abbesse et "mythographe' de Port-Royal" (n. 76 above), p. 94.

${ }^{95}$ Pierre Magnard, “Angélique de Saint-Jean; ou, l'esprit de résistance," Chroniques de Port Royal 34 (1985):13-32.

${ }^{96}$ A later reference to Angélique de Saint-Jean's abilities can be found in Mme de Sévigné's letter to Mme de Grignan dated November 29, 1679. Here she reports that Angélique's father once told her, "comptez que tous mes frères, et tous mes enfants, et moi, nous sommes des sots en comparaison d'Angélique." With regard to Angélique, Sévigné goes on to write: "jamais rien n'a été bon de tout ce qui est sorti de ces payslà [Port Royal], qui n'ait été corrigé et approuvé d'elle. Toutes les langues et toutes les sciences lui sont infuses. Enfin, c'est un prodige, d'autant plus qu'elle est entrée à six ans en religion": Mme de Sévigné, Correspondance: Tome 2, 1675-1680 (Paris, 1974), p. 748 .
} 
feminine ideal in the decade after $1653 .{ }^{97}$ While the previous ideal, the femme forte, was an androgynous model created by men, combining masculine strength and virtue with feminine patience, temperance, and chastity, the précieuse was a decidedly feminine model, created by women intellectuals. ${ }^{98}$ The précieuse embraced traditional feminine qualities at the same time that she sought to prove their compatibility with a woman's ability to learn and reason. She never flaunted her intellectual abilities but let them shine of their own accord through a polite respect for the established social order and a humble feminine posture. Angélique de Saint-Jean's report, written in narrative form for the most part, fit the précieuse model by showcasing her intellectual abilities while simultaneously adopting a humble tone in order to pay the necessary respect to Péréfixe, her male superior. She described the interrogation in a style of dispassionate observation, but the things she carefully observed-a movement of the eyes, a faltering of the voice, moments of silence-transformed her text into a narrative of high drama. The report also contains an important moment of rupture in which she switches abruptly from narrative to dialogue form. This stylistic break occurs at the very point at which she and the archbishop begin discussing her capacity to reason through visible perception. The switch to dialogue suddenly removes Angélique de Saint-Jean's authorial voice from the text and confronts the reader with the unmediated dialogue between herself and the archbishop. This textual transition both highlights the debate over her methods of reasoning and skillfully engages the reader to become the judge of this debate for him- or herself.

By emphasizing the question of reason, Angélique de Saint-Jean's report reflects her debt to recent developments in natural philosophy and religious polemic for means of combating Péréfixe's doctrine of human faith. In the seventeenth century, a transformation took place in theological debates between Catholics and Protestants that replaced a concern for doctrinal substance with a concern for the modes and attributes through which the faithful could assess the truth of a particular religious confession. ${ }^{99}$ As Catholic and Protestant theologians competed with one another to convert the influential and increasingly educated nobility at this time, a consensus developed among them

${ }^{97}$ DeJean (n. 52 above), p. 51. Angélique de Saint-Jean was connected to the salon culture of Paris through her father, Robert Arnauld d'Andilly, who regularly attended the salon of Mme de Rambouillet; see Alexander Sedgwick, The Travails of Conscience: The Arnauld Family and the Ancien Régime (Cambridge, Mass., 1998), pp. 204-5. In addition, many educated women from Parisian salons sought out Port Royal's directors for spiritual guidance; see Cécile Gazier, Les belles amies de PortRoyal (Paris, 1930); Dorothy Anne Liot Backer, "The Jansenists of Love," in Precious Women (New York, 1974), pp. 223-36.

${ }^{98}$ DeJean, p. 51.

${ }^{99}$ Rosa, "Seventeenth-Catholic Polemic” (n. 65 above), pp. 88-90. 


\section{Kostroun}

that reason was compatible with faith and that one could intellectually confirm the truth of a religion by assessing its "reasonableness." 100 The compatibility of faith and reason for Catholics such as the Port Royal nuns involved striking a delicate balance between the two. This balancing act was described by Pascal in his Pensées: "If we submit everything to reason our religion will be left with nothing mysterious or supernatural. If we offend the principles of reason our religion will be absurd and ridiculous." 101 Among the principles of reason in the seventeenth century were the notions that internal contradictions, signs of passion, and innovation were all marks of error. As we shall see, Angélique de Saint-Jean used these principles in a unique way, one that was significant to her gender because she used them to denounce the formula without entering into matters of doctrine. She carved a space for theologically ignorant women to denounce the formula by pointing out that nuns did not need to know theology to doubt the formula's legitimacy: the behavior of Péréfixe and other anti-Jansenists provided them with prima facie evidence of its error.

Angélique de Saint-Jean's interrogation began with Péréfixe asking her why she refused to sign the formula without qualification. When she replied that she had many reasons, he asked her to give him her best. She responded that the differences between the mandement circulated by the vicars-general of Cardinal de Retz and that circulated by Péréfixe filled her with doubt and that "I could not have a sincere belief in the matter of fact, nor could I be resolved to give proof of this belief by signing it, because I would be speaking against the belief that lies in my heart." 102 In this answer, Angélique de Saint-Jean reminded him that the first mandement accepted the nuns' silence on the matter of fact, whereas the second mandement demanded their signatures on this matter out of "human faith." She cited the discrepancy between these two mandements as the best evidence she had because of the obvious fact that two contradictory letters could not both be true. She told him, "This affair seemed to be so uncertain, and each person has explained it in [such] a different way, that it has put me in a state of great unease." ${ }^{103}$ The best reason for her doubt therefore had nothing to do with the content of the formula but rested on her ability to see the disagreement among bishops over how it should be signed.

Péréfixe replied that the reason for the differences among bishops was that some had requested the right to remain silent on the matter of fact in order to

\footnotetext{
${ }^{100}$ Susan Rosa, “'Il était possible aussi que cette conversion fût sincère': Turenne's Conversion in Context," French Historical Studies 18 (1994): 632-66.

${ }^{101}$ Blaise Pascal, Pensées, trans. A. J. Krailsheimer (London, 1966), p. 83.

${ }^{102}$ Angelique de Saint-Jean Arnauld d'Andilly, "Relation" (n. 93 above), p. 16: "Je ne pouvois avoir une créance sincère de ce fait, ni me resoudre à témoigner cette créance en le signant, parce que je parlerois contre le sentiment que j'ai dans le coeur."

${ }^{103}$ Ibid., p. 17: "Cette affaire me paroissoit si embarassée, et qu'on en parloit d'une manière différente, que cela me mettoit l'esprit dans une forte grande inquiétude."
} 
hide their unorthodox beliefs. He explained that it was typical of "all sectarians to seek out some evasive measure to hide [their doctrine] when the times are not favorable to them." ${ }^{104}$ Hearing this, Angélique de Saint-Jean pointed out that he must not really believe this since he had just told the nuns in his speech to the community that a signature on the matter of fact involved only a "human faith for which the fault in no way renders one heretical." ${ }^{105}$ Here again, she pointed out a contradiction: Péréfixe had previously claimed that the decision to sign on fact had nothing to do with doctrine. He replied with the qualification that his notion of "human faith" applied only to nuns and not theologians. ${ }^{106}$

He explained that there was no reason to suspect nuns of unorthodoxy if they expressed doubt. However, in the case of theologians, their refusal to subscribe to a matter of fact "gives one just cause to believe that it is because they are harboring forbidden ideas in their hearts." ${ }^{107}$ Angélique de Saint-Jean replied that she had seen this opinion expressed in a declaration by the king and that this was exactly why she remained suspicious, given that just a few years earlier theologians had openly debated the question of fact without any suspicion of heresy. ${ }^{108}$ By pointing out this "innovation" in the king's proclamation, she argued implicitly that it was illegitimate because innovation was a sign of error. Her response angered Péréfixe, and she wrote that he shouted at her so forcefully that it scared her. He yelled that the decision had been examined in Rome with all due forms and solemn procedure and that he was offended that she was accusing him of trying to deceive her. ${ }^{109}$

Angélique de Saint-Jean wrote in her report that she remained silent throughout his outburst. When he finally asked her if she had anything else to say, she replied that she noticed that this doctrine of "human faith" that he kept asserting to the nuns had "reduced people to a strange extremity." Once again, she undermined Péréfixe's position by alluding to the common belief that uncontrollable passion was a sign of unorthodoxy. By describing his behavior as extreme, she implied that he was the one guilty of error, not those like herself who respectfully asked to remain silent on the matter of fact. She added that this extremity stemmed from his trying to force her to believe

${ }^{104}$ Ibid.: "Tous les sectaires de chercher des faux-fuyants pour le mettre [le droit] à couvert, quand le tems ne leur est pas favorable."

${ }^{105}$ Ibid.: "Foi humaine dont le défaut ne rend point hérétique."

106 Ibid.

${ }^{107}$ Ibid.: "Il y a lieu de présumer justement que c'est qu'ils conservent dans le coeur les opinions condamnées."

${ }^{108}$ Ibid.: "Je lui répondis que cette supposition . . . étoit une des choses qui m'avoit encore davantage embarrassé l'esprit; voyant qu'on parloit si diversement d'un fait qui s'est passé depuis si peu d'années et au vû et au sçû de tant de personnes" (emphasis mine).

${ }^{109}$ Ibid., p. 18. 


\section{Kostroun}

something of which she was incapable: "[T]he more they assure us that things have always been a certain way, the more they increase my suffering, because it is beyond my power to believe one thing when I am absolutely sure of its opposite." 110

It is at this point that Angélique de Saint-Jean's text switches from narrative to dialogue form. After she stated that she was incapable of submitting to his doctrine of human faith, Péréfixe responded by asking why she believed that he was trying to deceive her. She replied: "I've seen for myself proof that things used to be different; how can I not believe my own eyes?"111 He responded that it was impossible that she could have seen any such proof because "things have always been as I say they are." 112 To this she replied: "I am not relying on hearsay, M[onsignor], I saw a report printed in the year that the five propositions were first presented to the theology faculty for examination in which the doctors who were opposed to them declared in no uncertain terms that the propositions were invented, dubious, and ambiguous and that no author supported them in the meaning that they give upon first impression. That certainly is not attributing them to Jansen." ${ }^{\prime 13}$ Here again, Angélique asserted her right to doubt the formula on the basis of her own observation of the disagreements over the texts. She took a risk with this response, however, because it gave Péréfixe an opening to reprimand her for involving herself in religious debates outside of the convent. He advised her: "You should try to remove yourself from these regrettable affairs, and here is an easy occasion for you to do so." 114 Ever poised, Angélique de Saint-Jean defended her right to follow these debates by stating that she had no other choice given Port Royal's history:

I believe, M[onsignor], that it is not so easy to remove ourselves from the persecution that we have been subjected to for the last twenty-five years. The signature was not the

${ }^{110}$ Ibid.: "Reduire les personnes à une étrange extrémité: car plus on nous donnes d'assurance que l'affaire s'est passé de la sorte, plus on augment ma peine."

${ }^{111}$ Ibid.: "J'ai vû de mes yeux des preuves du contraire, comment puis-je faire pour ne pas croire à mes propres yeux?"

${ }^{112}$ Ibid.: "La chose est constamment comme je vous dis." Just before this point, Angélique de Saint-Jean inserted a parenthetical note in the text stating that Péréfixe spoke with doubt in his voice: "en disant cela il changea le ton de sa voix, et ne parloit pas avec tant d'autorité": ibid., p. 17.

${ }^{113}$ Ibid., p. 18: "Je ne parle point par oüi dire, M[onseigneur], j'ai vû un écrit imprimée dès la première année que les $\mathrm{V}$ propositions furent présentées à la Faculté pour être examinées, par lequel les Docteurs qui s'y étoit opposés déclarent en propres termes que les propositions sont fabriquées, équivoques, ambiguës, et qui ne sont soutenuës par aucun Auteur dans le sens qu'elles présentent d'abord à l'esprit. Ce n'est pas là avoüer qu'elles sont de Jansénius."

${ }^{114}$ Ibid.: "Vous devriez tâcher de vous tirer de toutes ces fâcheuses affaires, et voici une occasion bien facile." 
beginning of this and I would highly doubt that it will be its end. I promise you that were it the case that we had nothing other than our own experience to persuade us that our superiors demand no more than a sign of our obedience, then it would be very difficult for us to believe that there was no other secret motivation for your current treatment of us. ${ }^{115}$

This passage, which marked the climax of Angélique de Saint-Jean's debate with Péréfixe over her ability to use reason, also marked her greatest use of humble language. Rather than stating forthrightly that Péréfixe's contradictory behavior gave the nuns reason to suspect his motives, she resorted to multiple conditional phrases that cast her arguments into a hypothetical mode. Her careful avoidance of direct language, shaped by bienséance - the respect for the social codes and order that made Péréfixe her superior-allowed her to assert her right to participate in these debates without directly accusing Péréfixe. This passage demonstrates how well Angélique de Saint-Jean fit the model of the précieuse, who, according to Madeleine de Scudéry, was as learned as she was humble. ${ }^{116}$ But like Scudéry and other précieuse authors, Angélique de Saint-Jean's humble tone was purely formal. ${ }^{117}$ In spite of her polite tone, she made it clear to Péréfixe that she did not believe him.

In addition to disagreeing with the archbishop, Angélique de Saint-Jean's report artfully discredited him by drawing attention to the contradictions of his theories and the irrationality of his behavior. By focusing on these matters, she reminded Péréfixe (and her intended readers) that the faithful had legitimate ways to learn truths about religion outside formal theological knowledge. Moreover, she demonstrated how the development of this rational religion had special significance for women. At the very moment when the Port Royal nuns saw Péréfixe's doctrine of human faith as denying women's spiritual equality on the grounds of their ignorance, they countered him with a distinction between religion as doctrine and religion as procedure. The necessary condition for this distinction, however, was the recognition of women's rational capacity because faith could no longer stand without reason. This development reveals how truly paradoxical the nuns' position had become, because the defense of their faith now rested entirely on their ability to convince the archbishop that they were both "naturally" ignorant and highly rational at the same time.

${ }^{115}$ Ibid.: “Je pense, M. qu'il n'est pas si aisé de sortir de la persécution où nous sommes exposées depuis vingt-cinq ans. La signature n'en a pas été le commencement, et je douterois fort qu'elle en fût la fin. Je vous avoüe que quand nous n'aurions que nôtre propre expérience, pour nous persuader qu'on demande autre chose de nous qu'une marque de nôtre obeissance, il nous seroit bien difficile de croire qu'il n'y eût pas d'autre cause secrette de la conduite qu'on tient sur nous aujourd'hui."

116 Timmermans (n. 54 above), p. 326.

${ }^{117}$ Ibid., p. 114. 


\section{Kostroun}

\section{CHRISTINE BRIQUET: ORDER}

A few days later, on June 13, Péréfixe interviewed Madeleine de Sainte-Christine Briquet. Only twenty-three years old at the time, Briquet was the youngest of the nuns to write a report of her interrogation. Structurally her report resembles Dupré's, as it was written entirely in the form of a dialogue. In terms of tone, however, her report is closer to Angélique de Saint-Jean's, with its longer entries, fluid dialogue, and regular commentary on Péréfixe's mood and reactions. By providing this information, Briquet demonstrates how she carefully measured her words to soften and appease the archbishop whenever he showed signs of anger. At one point in her report, she frankly admits in a parenthetical note her constant need to manage the archbishop's emotions:

It may seem that I spoke too freely up to this point. But I did this seeing that he was enjoying himself and that the more I spoke like this, the more he seemed to be accepting of what I said. Besides, he had a way of becoming easygoing enough not to be bothered by our reasons, which were sometimes a little strong, when he did not want to take offense, even though he knew very well how to use his authority to silence others and to change the subject without responding to what was said to him. ${ }^{118}$

Briquet was aware that the conversation walked a fine line between gallant repartee and oppressive interrogation. Her goal, therefore, was to maintain a spirit of polite, bantering conversation. By assigning herself a civilizing role against Péréfixe's notorious temper, she too was adopting the précieuse as a literary model, but in the sense of the honnête femme. The honnête femme was the woman whose primary purpose was to promote civilité, or refined social manners, through pleasant and amusing conversation. ${ }^{119}$ As a précieuse, an important feature of the honnête femme was her respect for social order. Although her purpose was to instruct others in the ways of civility, she was to do this without exceeding the bounds of propriety deemed appropriate to her place in society. ${ }^{120}$

${ }^{118}$ Madeleine de Sainte-Christine Briquet, "Relation de ma Soeur Madeleine Christine Briquet," in Divers actes, lettres et relations (see n. 1 above), p. 30: "Tout ce que j'ai dit jusqu'ici peut paroitre trop libre: mais je l'ai fait, voyant qu'il s'en divertissoient, et qu'il sembloit que plus j'en disois, et mieux il le recevoit. Au surplus il a un moyen assez commode pour ne se pas embarrasser des raisons un peu fortes qu' on lui pourroit dire, quand il ne veut pas s'en offenser; car il sçait bien se servir de son autorité pour faire taire les personnes, et changer de discours, sans répondre à ce qu'on lui dit."

${ }^{119}$ Honnêteté was also an important concept for Jansenist writers such as Blaise Pascal and Pierre Nicole, who conceived it as a way to bridge religious and civil virtues; see Nannerl Keohane, "Self-Love and Society: Jansenism and the Honnête Homme," in Philosophy and the State in France: The Renaissance to the Enlightenment (Princeton, N.J., 1980), pp. 283-311.

${ }^{120}$ Maclean (n. 23 above), p. 125. 
Briquet used the literary rhetoric of the honnete femme, with its emphasis on civility and social order, to help her challenge the formula on the grounds that it violated the jurisdictional order of women in the church. At the very beginning of the interview she referred to the clause in the nuns' second heading by stating that she did not want "to take part in something that is very far above my capacity." If Briquet argued like a good lawyer, this was probably because she was collaborating with her father, Etienne Briquet, and her uncle, Jérôme Bignon, each an avocat général in the Parisian Parlement. ${ }^{121}$ These powerful lawyers defended Port Royal in the summer of 1664, when Péréfixe seized administrative control over the convent as part of his efforts to extract the nuns' signatures. ${ }^{122}$ Port Royal was an ancient institution endowed with complex privileges and exemptions through its foundation and charter. These lawyers filed suit in defense of the convent's institutional privileges and lobbied for its cause in the Parlement. When Péréfixe took control of the convent, the nuns' refusal to sign the formula and their families' defense of Port Royal's jurisdiction became two faces of the same battle. For parlementaire families such as that of Christine Briquet, the battle against Péréfixe was as much a legal and jurisdictional matter as it was a personal and religious one.

Briquet's strategy throughout her interrogation was to shift Péréfixe's attention away from herself as an individual nun and toward what was appropriate for her sex and office. In this way, she reinforced the point that the question was one of order. For example, at one point Péréfixe offered to show her Jansen's book so that she could see for herself that the propositions condemned in the bulls were present in the text. In particular, he offered to show her the first proposition, since this one appeared word for word in the Augustinus. He said, "Very well, I will bring you the book of M. Jansen, I will show you the first proposition in its precise terms, and after that you will sign, right?" 123 Briquet responded that his efforts would be "quite useless" because Jansen's book was a Latin text that she could not understand. Péréfixe was not satisfied with this response and continued to press, saying, "I'll explain it to you word by word." She replied once again that his efforts would be useless because the material in the book was "beyond my capacity." 124 She then reminded him that

${ }^{121}$ Briquet's interrogation report provides evidence of this collaboration when she cites her uncle's legal opinion on the nuns' signatures as possibly bearing false witness and thus rendering the nuns culpable: Briquet, p. 26. For information about Briquet's family background, see Newton (n. 24 above), pp. 304-6.

${ }^{122}$ Péréfixe seized control by exiling the convent's officers and replacing them with nuns from the Visitation order; see Arnauld, “Apologie pour les Religieuses de Port Royal" (n. 43 above), pp. 170-75.

${ }^{123}$ Briquet, p. 30: "Oh bien, je vous apporterai le livre de M. Jansenius, je vous y ferai voir la première proposition en terme formel; et après cela vous signerez: n'estce pas?"

${ }^{124}$ Ibid., p. 30: "Bien inutile"; "Mais je l'expliquerai mot à mot"; "[les matières dont il traite] sont au dessus de ma capacité." 


\section{Kostroun}

theologians, not nuns, should study Latin texts: "But if you would like, $\mathrm{M}$ [onseigneur], to take the trouble to point out these propositions to those theologians who do not see them, they can be persuaded." 125 By emphasizing that the examination of this text was the responsibility of theologians, not nuns, Briquet again turned the discussion away from her intellectual abilities and toward the order of the church in which theologians alone had the right to interpret theological texts.

In spite of Briquet's efforts to turn the discussion away from the specifics of Jansen's text, Péréfixe persisted: "At least, my daughter, you know very well how to read in Latin, and when you see the Pater Noster in two books, you can judge easily if there is a difference between them. I will bring you the book of M. Jansen and a copy of the proposition and all you have to do is read." 126 By suggesting that Briquet could easily decipher Latin texts by perceiving differences and applying her reason, Péréfixe was setting a trap for her. Just as Angélique de Saint-Jean had previously argued that women could use natural reason to determine religious truth, Péréfixe now turned this argument against Briquet to persuade her that she could determine the truth about the propositions without formal theological knowledge. Briquet outwitted Péréfixe, however, by responding, "But I marvel at how it can be, that people with judgment argue that [the propositions] are not in the Augustinus when it is so easy to demonstrate the contrary, and I am surprised that they are not yet convinced." ${ }^{27}$ She undermined Péréfixe's claim that the propositions were easily found in Jansen's text by stating her "surprise" that trained theologians continued to disagree over its meaning. Her seemingly innocent tone allowed her to appear humble and ignorant while she was in fact reminding Péréfixe that the interpretation of texts was a complex and ambiguous practice. Clearly, she could not identify the propositions in the Augustinus by pointing out the actual words if theologians were in disagreement over the meaning of those words. By suggesting that there was more to reading texts than recognizing words, Briquet upheld her point that nuns were ignorant of formal theological knowledge by virtue of the church's own order and should be treated accordingly. Péréfixe persisted in his offer to show her the first proposition in Jansen's

\footnotetext{
${ }^{125}$ Ibid.: "Mais si vous voulez M[onseigneur] prendre la peine de faire voir les propositions aux théologiens qui ne les y voyoient pas, ils sont capables d'en être convaincus."

${ }^{126}$ Ibid.: "Au moins, ma fille, vous sçavez bien lire en Latin, et quand vous voyez le Pater Noster dans deux livres, vous jugez bien s'il y a de la difference, je vous apporterai le livre de M. Jansenius et la proposition, vous n'aurez qu'à la lire."

${ }^{127}$ Ibid.: "Mais j'admire comment il se peut faire que des personnes qui ont du jugement soutiennent qu'elles [les propositions] n'y [Augustinus] sont pas, s'il est si facile de leur faire voire le contraire, et je m'étonne qu'on ne les en ait pas encore convaincus."
} 
text, but Briquet outwitted him once again by asking, "But M[onseigneur], you only talk about showing us the first proposition: is this because it is the only one that appears in the book of [Jansen]?" 128 She wrote that these words caused Péréfixe to smile. He paused and responded, "Ah, but you know well, my daughter, that a single idea can be expressed in many different ways." 129 The archbishop smiled because he realized that she had cornered him. Since the first proposition was the only one appearing in Jansen's text word for word, Péréfixe was forced to concede Briquet's earlier point that the interpretation of texts demanded training beyond the simple act of recognizing words. In this way, he tacitly agreed with her that since women were banned from any formal training in theology, they had to be treated as ignorant by the church.

As these excerpts from her report show, Briquet succeeded in keeping Péréfixe's temper in check. When she cornered him with her arguments, he smiled appreciatively rather than exploding at her. His willingness to participate in a polite, bantering conversation was probably out of respect for her family's exalted social status as much as from the strength of her arguments. Whatever the case, Briquet's ties to the legal profession appear to have informed the content of her interrogation. By repeatedly deflecting the topic of conversation from her individual abilities to what was appropriate for nuns as members of the church, she stressed that the nuns' refusal to sign was a matter of respect for jurisdictional order as much as personal belief. This argument was the nuns' most overtly political; arguments over jurisdiction and order dominated political debates at the time. Recent studies now show that the defense of traditional rights and privileges was the most effective form of political protest under absolutism. ${ }^{130}$ Scholarship on Jansenism has also supported this view by showing that Louis XIV was ultimately forced to abandon the formula and his quest for signatures by the Peace of Clement IX in 1669 because of the jurisdictional concerns of French bishops. ${ }^{131}$ Given the prevalence of jurisdictional debates under absolutism, we can better appreciate why the nuns insisted on sexual difference as a condition for refusing the formula. This strategy not

${ }^{128}$ Ibid., p. 31: "On ne nous parle jamais que de nous faire voir la première proposition: est-ce qu'il n'y a que celle-là qui soit dans le livre de M. d'Ypres?"

${ }^{129}$ Ibid.: "Hé mais, ma fille, vous sçavez bien qu'une même chose peut être dite en differentes manières."

${ }^{130}$ Revisionist historians of absolutism have brought our attention to this form of political resistance as they highlight the "traditional" aspects of Louis XIV's monarchy. They have argued successfully that Louis XIV was not concerned with replacing old political structures with new ones so much as he was with tightening his reins over the structures already in place; see William Beik, Absolutism and Societv in SeventeenthCenturv France (Cambridge, 1985); Roger Mettam, Power and Faction in Louis XIV's France (New York, 1988); Andrew Lossky, Louis XIV and the French Monarchy (New Brunswick, N.J., 1994).

${ }^{131}$ Sedgwick, Jansenism (n. 6 above), p. 138. 


\section{Kostroun}

only confounded Louis XIV with the paradox of his command for the nuns' signatures and the church laws' command for female silence; it also poised them to formulate the most politically shrewd form of protest available under absolutism.

\section{Three Interrogations as Publishing Strategy}

As we have seen, each of these nuns drew upon rhetorical styles available to them as women to fashion cultural, intellectual, and legal stances for their defense. The rhetoric both of Teresa of Avila and of the précieuses was marked by a formal respect for the "natural" hierarchy of gender at the same time that it allowed women to assert their spiritual and intellectual autonomy. Such rhetoric was well suited for the nuns, who defended their "natural" ignorance of the formula while tapping into contemporary political and intellectual debates over authority and obedience, the compatibility of reason with religion, and legal jurisdiction and order. These were important debates in the seventeenth century, and by linking their case to these broader issues the nuns were possibly developing a publishing strategy to present their case to a reading public that was not necessarily Jansenist in sympathy.

By "publishing strategy" I mean a self-conscious effort to prepare literary material for public consumption. The preparation of texts did not necessarily involve the printing process in the seventeenth century, as writers did not always choose to disseminate their works in print. This was especially true for women, who always faced social restrictions in any pursuit of public attention and recognition. Although some women did print their works, others avoided the potential risks that printing entailed and instead circulated their works in manuscript form. Such was the case of Mme de Sévigné, for example, who cultivated a literary reputation for herself while remaining within the respectable bounds of dutiful motherhood and feminine modesty. ${ }^{132}$ Similarly, the Port Royal nuns shunned the printing press and wrote as humble, pious women who sought nothing but to help defend the truth by sharing their writings with a small group of family and friends. These friends, however, occasionally took it upon themselves to print the nuns' writings, and the nuns, knowing this, seemed to have collaborated by writing polished texts and by conforming to women's literary conventions at the time. These conventions included a natural style devoid of classical references that was both entertaining and informative. ${ }^{133}$ In addition, women tended to write in genres, such as letters, that negotiated the gray area between factual reporting and literary invention, between reality and fiction. As we saw above, the nuns' reports fit these con-

${ }^{132}$ Longino Farrell (n. 72 above), p. 34.

${ }^{133}$ Timmermans (n. 54 above), pp. 137-39. 
ventions, especially in terms of ambiguity between fictional and nonfictional genres. We will never know for sure how much of these conversations was reported verbatim and how much was invented because the only other witness, Péréfixe, had promised to keep the meetings confidential and, accordingly, burned his notes from them in front of the community immediately after they ended. ${ }^{134}$

The literary conventions that apply to the nuns' interrogation reports also apply to Pascal's Provincial Letters. The similarity between these texts raises the possibility that Pascal's famous letters served as another model for the nuns' writings. Composed a decade earlier in 1656-57, the Provincial Letters attacked Jesuit morals and casuistry under the guise of entertaining letters "to a provincial friend" who supposedly reported on the real conversations between a layman (called Montault) and several theologians. We know that copies of Pascal's Provincial Letters were delivered to Port Royal shortly after their publication and that some of the nuns read his work. ${ }^{135}$ Although there is no direct evidence that the nuns modeled their reports after Pascal's letters, the overall fame of his letters at the time, along with the nuns' personal relationship to him through his sister Jacqueline, suggest the possibility that the nuns drew upon Pascal for literary inspiration.

A distinguishing feature of the Provincial Letters is Pascal's method of gradually drawing his readers to his side of the argument. Over the course of the eighteen letters, Pascal's argument progresses from an initial assertion that Antoine Arnauld's expulsion from the Sorbonne was the result of personal quarrels among theologians to the assertion that this event has relevance for all because it exposes the inherent laxity of Jesuit casuistry. According to Pascal, this laxity derives from the casuists' use of inaccessible and obscure language to manipulate meaning. Pascal gradually unmasks the dangers of Jesuit casuistry for his readers as Montault, his naive but sensible character, engages in a series of fictional conversations with expert theologians about what is at stake in Arnauld's expulsion. In the opening letters of the series, Montault comes across as naive because he is easily duped by the semantic manipulations of his Jesuit interlocutors. Through his sincere efforts to understand the intricacies of Jesuit theology by applying his reason and common sense, Montault eventually comes to recognize the Jesuit linguistic labyrinths for what they are, and, by the eleventh letter, he is able to dismantle them on his own. As Montault becomes more aware of the Jesuits' methods, his persona is transformed from that of a buffoon to that of a sophisticated agent of satire. ${ }^{136}$

\footnotetext{
${ }^{134}$ Péréfixe told the nuns that he burned his notes to prove that his promise of confidentiality was sincere; see Besoigne (n. 70 above), 1: vi: 488.

${ }^{135}$ Sainte-Beuve (n. 73 above), 2:161.

${ }^{136}$ Richard Parrish, Pascal's "Lettres Provinciales": A Study in Polemic (Oxford, 1989), pp. 11-13.
} 


\section{Kostroun}

When we examine the nuns' interrogations in the order in which they were assembled, we see a similar progression from farce to satire, albeit on a much smaller scale. As the initial text of the series, Dupré's interrogation parallels Pascal's first letter as the point where the power discrepancy is greatest between the two interlocutors. Dupré and Montault are both portrayed as inept characters whose attempts at speech are repeatedly cut short by the expert theologians. These theologians in turn appear ridiculous for overreacting to their naive interlocutors by interrupting them with frustrated anger and insults. The farce eventually disappears as the naive interlocutor begins engaging his or her reason and common sense to assess religious truth. In the case of the nuns, Angélique de Saint Jean emphasizes the correlation between reason and truth through humble, indirect arguments. Here, the reader begins to suspect the Port Royal nuns of a false naïveté because of the discrepancy between the force of Angélique de Saint Jean's arguments and her claims to humility.

In similar fashion, the reader of Pascal's Letters begins to suspect Montault of a false naïveté by the fourth letter. Here Montault examines various theological texts for himself with the help of two experts. When Montault asks his Jesuit expert to clarify the texts in layman's terms, it becomes evident that the Jesuit theologian cannot translate these texts into plain language without contradicting himself. In the eleventh letter, Montault admits that his letters are satirical by arguing that satire is the natural and inevitable response to the unnatural and unreasonable manipulation of language by the Jesuits. ${ }^{137}$ Similarly, Briquet's report was the most openly satirical of the three. Her bantering style, the way she cornered the archbishop with her arguments, his wry smiles - all were internal cues to the secret understanding between them that her naïveté was a false one. In addition, her report climaxes at the point where Péréfixe conceded that "a single idea can be expressed in many different ways." In extracting this admission, Briquet, like Pascal, had successfully unmasked the problem with casuistry: that meaning can easily be manipulated through the removal or reversal of linguistic contexts.

The parallels between the nuns' interrogations and Pascal's Provincial Letters, with their use of dialogue, satire, and argument against linguistic manipulation, suggest that the nuns composed these reports to educate and persuade a lay readership. Of all those in the church asked to sign the formula, the nuns were best suited for an appeal to the public, because they were in a position with which the laity could most easily identify. Ignorant of theology, the nuns had to depend on the advice of experts and on their own common sense to determine the truth of the formula. In addition, because Port Royal was famous for its reform, the nuns already had a reputation that commanded respect and

${ }^{137}$ On Pascal's debt to Antoine Arnauld for his patristic sources on humor and satire, see Gérard Ferreyrolles, Pascal: Les Provinciales (Paris, 1984), pp. 29-30. 
admiration. With their record of perfect religious obedience, they could be trusted to ignore material and political considerations in the name of religious truth.

\section{Conclusion: Jansenism, Gender, AND EARly Modern Feminism}

Although the formula crisis ended in 1669, the Port Royal nuns' relation to royal authority remained troubled. In 1705 a similar crisis arose when the Port Royal nuns were ordered to sign a new formula accepting another anti-Jansenist bull issued by Pope Clement XI. ${ }^{138}$ Once again, the nuns refused to sign, but this time they did not enjoy the support among bishops that had helped to save them in 1669. In the fall of 1709, Louis XIV ordered the destruction of Port Royal and sent armed guards to escort the nuns to other convents in France, where they spent the remainder of their lives in exile. Although Port Royal was gone forever, friends and supporters kept the memory of the convent alive in print. When the Jansenist controversy rekindled in the following decade, the majority of the nuns' writings, including the three interrogation reports, were published and circulated throughout France. ${ }^{139}$ The flood of works commemorating Port Royal that were published during the eighteenth century has secured these nuns a lasting place in the annals of French history.

In spite of the Port Royal nuns' fame for standing up to Louis XIV, these women are typically excluded from any discussion of early modern feminism. This is surprising, considering that feminist scholars have established seventeenth-century France as a crucial period for the development of feminist thought. ${ }^{140}$ The reason for the nuns' exclusion from feminist narratives has been their failure to measure up to the ideological criteria set by modern scholars for the definition of feminism. The nuns fail to meet these criteria because they never explicitly condemned male dominance or consciously asserted women's spiritual and rational equality in the course of their struggles. Political theorists have taught us, however, that explicit use of language is not always

\footnotetext{
${ }^{138}$ Vineam Domini (1705). For the origins of this bull and its implications for Port Royal, see Albert Le Roy, La France et Rome de 1700 à 1715 (Geneva, 1976).

139 The catalyst for the renewed controversy was the publication of the bull Unigenitus in 1713 against Pasquier Quesnel's Reflexions morales. On the printing of Port Royal's documents as part of this controversy, see B. Robert Kreiser, Miracles, Convulsions, and Ecclesiastical Politics in Early Eighteenth-Century Paris (Princeton, N.J., 1978), p. 12; Catherine Maire, De la cause de Dieu à la cause de la nation: Le jansénisme au XVIIIe siècle (Paris, 1998), pp. 47-48, 477-84.

${ }^{140}$ Elizabeth C. Goldsmith and Dena Goodman, Going Public: Women and Publishing in Early Modern France (Ithaca, N.Y., 1995), p. 5; Stuurman, "L'égalité des sexes" (n. 22 above), pp. 67-68.
} 


\section{Kostroun}

an accurate measure of political intent. ${ }^{141}$ As Archbishop Péréfixe said, "a single idea can be expressed in many different ways." The Port Royal women did not openly voice a "feminist" position, but the force of their arguments within the discursive and institutional contexts in which they were made was such that they were able to claim authority for themselves as women in a patriarchal society that denied them this authority.

Considering the force of the nuns' language within their particular political and religious context is one key for understanding their feminism. Another key is recognizing their use of gender as a political construct. By insisting upon the inevitable quality of their theological ignorance, the nuns' strategy reflected a larger truth about gender and power in the seventeenth century. As Joan Scott says, "to vindicate political power, [gender relations] must seem sure and fixed, outside human construction, part of the natural or divine order." ${ }^{142}$ Seventeenth-century conceptions of gender supported and reproduced patterns of patriarchal control in just this way. As we have seen, the Port Royal nuns offer an example of women exploiting the paradoxes of their subordinate position to open a small but precious space for autonomy. The nuns attacked Louis XIV's religious policies by linking their stance to politically urgent questions about the authority of reason in religious doctrine and about the proper order and jurisdiction of corporate institutions. Tying their particular case to these wider political issues, the nuns implicitly recognized the force of a further consequence of Scott's argument: "[By seeming part of the natural or divine order], the binary opposition and the social process of gender relationships both become part of the meaning of power itself; to question or alter any aspect threatens the entire system." ${ }^{143}$ The nuns represented Louis XIV's command for their signature as a threat to all, not only to Jansenists, by highlighting the ways in which it violated basic principles of religion, reason, and law. In this way, they asserted their right to conscience while simultaneously denouncing Louis XIV's religious policies as an illegitimate use of authority.

The decision to call these women "feminist" ultimately comes down to a matter of definition. On the one hand, some would claim that the term "feminist" should not be applied to the early modern period, as the term is inherently anachronistic. ${ }^{144}$ On the other hand, most scholars, finding the term too useful or convenient to abandon, define it in relation to the questions of gender, power,

${ }^{141}$ Quentin Skinner, "Meaning and Understanding in the History of Ideas," in Meaning and Context: Quentin Skinner and His Critics, ed. James Tully (Princeton, N.J., 1988), pp. 61-63.

${ }^{142}$ Joan Wallach Scott, Gender and the Politics of History (New York, 1988), p. 49.

${ }^{143}$ Ibid.

${ }^{144}$ Karen Offen, "Defining Feminism: A Comparative Historical Approach," Signs 14 (1988): 134 
and authority that were particular to the early modern period. ${ }^{145}$ In this essay, I have argued that the nuns were feminist by defining feminism in terms of paradox. Joan Scott first applied this definition of feminism to modern women who used the inherent paradox behind the language of universal rights (that women were denied basic rights at the very moment when rights were declared "universal") to assert their civil equality. Scott credits the eighteenth-century democratic revolutions with providing the conditions within which the feminist paradox was first able to operate. ${ }^{146}$ The case of the Port Royal nuns, however, reveals that women had already used this kind of paradox to assert their rights (in this case, the right to conscience and spiritual equality) well before the eighteenth century.

The definition of feminism as paradoxical is likely to sit well with scholars of the early modern period for whom paradox is already a ubiquitous and recurring theme in feminist literature. ${ }^{147}$ But recognizing paradoxes is not always the same as reading for paradoxes. In the case of the Port Royal nuns, we can call their resistance feminist because they recognized the inherent contradiction of the political situation in which they were caught. They were selfproclaimed loyal subjects of the Bourbon monarchy and of the Catholic Church who were asked to sign a formula that put their religious beliefs at odds with their political allegiance. Not wanting to compromise their beliefs, but not wanting to disobey their king and male superiors either, these women responded by exploiting the paradox implicit in Louis XIV's demand that women publicly take sides on a theological issue. The nuns exploited this paradox not simply as a strategy of opposition but as a way to confront the monarchy with the fundamental flaws in its use of authority. At the same time that they challenged the king, the nuns modeled themselves after other women of authority, ranging from Teresa of Avila to the précieuses of the Parisian salons, in order to assert legitimate authority in their own right. In the end, this creative appropriation of other women's strategies is perhaps the nuns' most significant contribution to our understanding of early modern feminism. ${ }^{148}$ It illustrates

${ }^{145}$ Jordan (n. 15 above), pp. 2-21; Kelly (n. 50 above), pp. 66-67; Offen, "Defining Feminism," p. 134 n. 34; Carolyn Lougee, Le paradis de femmes (Princeton, N.J., 1976), p. 7; Natalie Zemon Davis, foreword to The Book of the City of Ladies, by Christine de Pizan, trans. Earl Jeffrey Richards (New York, 1982), pp. xviii-xix; Akkerman and Stuurman, "Feminism in European History," in Akkerman and Stuurman, eds., Thought (see n. 22 above), pp. 3-5.

${ }^{146} \mathrm{Scott}$, Only Paradoxes (n. 12 above), p. 3.

147 Jordan, pp. 66, 104; Maclean (n. 23 above), p. 62; Danielle Haase-Dubosc and Eliane Viennot, eds., Femmes et pouvoirs sous l'ancien régime (Paris, 1991), p. 7.

${ }^{148}$ Akkerman and Stuurman argue for precisely this kind of attention to the "highly idiosyncratic ways" in which thinkers adopted feminist ideas across time to reconstruct the history of feminism: Akkerman and Stuurman, p. 9. 


\section{Kostroun}

how feminist thought did not develop in a smooth, unilateral direction but, rather, emerged from the multiple and sometimes competing experiences of women struggling to assert political authority in the early modern period. To deny them the status of feminists would be an exercise in casuistry of just the type they so successfully satirized. 